OPEN ACCESS

Edited by:

Artur Mayerhofer

Ludwig Maximilian University of

Munich, Germany

Reviewed by:

Subeer Majumdar,

National Institute of Animal

Biotechnology (NIAB), India

Silvana A. Andric,

University of Novi Sad, Serbia

*Correspondence:

Wan-Xi Yang

wxyang@zju.edu.cn

${ }^{\text {t}}$ These authors have contributed equally to this work

Specialty section: This article was submitted to

Reproduction,

a section of the journal

Frontiers in Endocrinology

Received: 18 December 2021 Accepted: 01 February 2022

Published: 24 February 2022

Citation:

Wang J-M, Li Z-F and Yang W-X (2022) What Does Androgen

Receptor Signaling Pathway

in Sertoli Cells During Normal

Spermatogenesis Tell Us?

Front. Endocrinol. 13:838858.

doi: 10.3389/fendo.2022.838858

\section{What Does Androgen Receptor Signaling Pathway in Sertoli Cells During Normal Spermatogenesis Tell Us?}

\author{
Jia-Ming Wang ${ }^{\dagger}$, Zhen-Fang $\mathrm{Li}^{\dagger}$ and Wan-Xi Yang* \\ The Sperm Laboratory, College of Life Sciences, Zhejiang University, Hangzhou, China
}

Androgen receptor signaling pathway is necessary to complete spermatogenesis in testes. Difference between androgen binding location in Sertoli cell classifies androgen receptor signaling pathway into classical signaling pathway and non-classical signaling pathway. As the only somatic cell type in seminiferous tubule, Sertoli cells are under androgen receptor signaling pathway regulation via androgen receptor located in cytoplasm and plasma membrane. Androgen receptor signaling pathway is able to regulate biological processes in Sertoli cells as well as germ cells surrounded between Sertoli cells. Our review will summarize the major discoveries of androgen receptor signaling pathway in Sertoli cells and the paracrine action on germ cells. Androgen receptor signaling pathway regulates Sertoli cell proliferation and maturation, as well as maintain the integrity of blood-testis barrier formed between Sertoli cells. Also, Spermatogonia stem cells achieve a balance between self-renewal and differentiation under androgen receptor signaling regulation. Meiotic and post-meiotic processes including Sertoli cell - Spermatid attachment and Spermatid development are guaranteed by androgen receptor signaling until the final sperm release. This review also includes one disease related to androgen receptor signaling dysfunction named as androgen insensitivity syndrome. As a step further ahead, this review may be conducive to develop therapies which can cure impaired androgen receptor signaling in Sertoli cells.

Keywords: androgen receptor, Sertoli cell, signaling pathway, spermatogenesis, androgen insensitivity syndrome

\section{INTRODUCTION}

Male infertility is currently a major problem worldwide and causes substantial psychological and social distress (1). It not only puts a huge economic burden on patients, but also poses a great challenge to the health-care system. Male infertility is due to abnormal sperm parameters in the male partner and contributes to $50 \%$ of all cases of infertility, highlighting the importance of normal spermatogenesis $(2,3)$. 
Spermatogenesis is a complex process that is under precise regulation. Starting from spermatogonia stem cell (SSC) producing differentiated spermatogonia, spermatogonia transform into spermatocytes which then undergo meiotic divisions to produce round spermatids (4). Round spermatids undergo cytodifferentiation to form spermatozoa, which are ultimately released to the lumen (5).

As the only somatic cell type in seminiferous tubules (6), Sertoli cells (SCs) make normal spermatogenesis possible by providing the nutrition necessary for the development of germ cells (7), forming blood-testis barrier (BTB) between SCs in mammalian testes $(8,9)$, attaching to germ cells (GCs) through adherens junctions (10) and phagocytosing apoptotic GCs for recycling (11). SCs function like a nurse to take good care of spermatogenesis (12). These functions of $\mathrm{SCs}$ are regulated by both extrinsic and intrinsic factors. The former factors include hormone and paracrine molecules and the latter include genomic regulators. Here, we review androgen receptor (AR) signaling pathway in SCs, a pathway that provides an excellent example of a combination of extrinsic and intrinsic regulation. AR begins its expression 3-5 days after birth in rodent testis while AR expression begins about 5 months after birth in men $(13,14)$. In men, its expression in SCs peaks during stage III of the six stages (15). AR signaling pathway can be classified into classical signaling pathway and non-classical signaling pathway with different functions and different efficiencies. It has been shown that abnormal AR signaling can impair spermatogenesis (16). Although decades of studies have brought us a better understanding of AR signaling in spermatogenesis using altered testosterone signaling model, Sertoli cell androgen receptor knockout model, specificity-affecting androgen receptor knock in model as well as Ribo-Tag mouse model, not enough information has been gained to lift the veil of its beauty. As a result, it is necessary to review current work about androgen receptor signaling pathway in SCs and put forward suggestions for future studies. Ultimately, all of our hard work aims to achieve "bench to bedside" translation that can be used to develop therapies for illnesses related to hormone dysfunction.

We surveyed articles in the PubMed database using the following search terms: androgen receptor ${ }^{\star}$, Sertoli cell ${ }^{\star}$, spermatogonia*, maturation and differentiation ${ }^{*}$, spermatogenesis $^{*}$, meiosis ${ }^{*}$, spermatid $^{*}$ and androgen-insensitive syndrome $e^{*}$. We will present this review at the cellular/molecular level in six parts: SC proliferation and maturation, SSC self-renewal and differentiation, spermatocyte meiosis, BTB integrity maintenance, Sertoli cell - Spermatid adhesion, and sperm release (Figure 1). The experimental models involved in this review include mice, rats, boars, lambs, zebrafish and humans. We include some contradictory results in this review and present our opinions. We also discuss androgen insensitive syndrome (AIS), briefly reviewing its pathogenesis, diagnosis and offering suggestions for better diagnosis and treatment.

\section{STRUCTURE OF ANDROGEN RECEPTOR}

The gene encoding $\mathrm{AR}$ is located on the $\mathrm{X}$ chromosome, belonging to nuclear receptor subfamily 3 , group $\mathrm{C}$, member 4 .
It consists of 8 exons that encode 4 domains: an N-terminal domain (exon 1), a DNA-binding domain (exon 2 and exon 3), a hinge region that contains the nuclear localization signal (exon 3 and exon 4) and a ligand-binding domain (exons 4-8) $(17,18)$.

The N-terminal domain contains activation function domain1 which is constitutively active (15). The DNA-binding domain contains two zinc fingers to complex with its hormone response element, where each of them is coordinated by four cysteines. One zinc finger is involved in direct DNA binding mediated by the $\mathrm{P}$ (proximal) box, which recognizes the specific hormone response element half-site 5'-AGAACA-3'. The other zinc finger is involved in a "head-to-head" receptor dimerization through the $\mathrm{D}$ (istal) box (19-22). The hinge region contains the nuclear localization signal which is essential for nuclear import. Residues from the major nuclear localization signal site 629-RKLKKL-634 contribute to importin $\alpha$ binding (23-25). Then the ligandbinding domain consists of $11 \alpha$-helices and two small, twostranded $\beta$-sheets arranged in a typical three-layer antiparallel helical sandwich fold $(26,27)$. Binding of androgen to ligandbinding domain can activate the receptor. Both of these structures are important for androgen receptor function, though the structure of full-length androgen receptor has not been solved yet.

\section{OVERVIEW OF ANDROGEN RECEPTOR SIGNALING PATHWAY IN SERTOLI CELLS}

In adult rodent testes, the AR expression level in SCs is low except during stage VI-VIII of the seminiferous epithelium (28). In men, its expression in SCs peaks during stage III of the six stages (29). This stage-specific peak of AR expression in SCs is coordinated with initiation of testosterone-dependent processes that is essential for spermatogenesis such as appearance of preleptotene spermatocytes and the initiation of meiosis during stages VII-VIII, as confirmed by Sertoli cell androgen receptor knock out model and androgen receptor knock out model (5). It is reasonable that AR signaling in SCs mediates paracrine action on germ cells and autocrine action on themselves to form a microenvironment for meiosis completion.

Stimulated by luteinizing hormone in the pituitary gland which is part of the hypothalamus-pituitary-gonadal axis, Leydig cells produce androgen. When androgen saturates the AR of SCs and binds to AR, the AR signaling pathway is activated (30). Testosterone is the most abundant androgen produced in the testis. Another important androgen is dihydrotestosterone (DHT), which is produced by peripheral tissues where $5 \alpha$ reductases reduce testosterone to DHT $(31,32)$. When hormone levels in the targeted tissue are low, DHT is more potent than testosterone due to its higher binding affinity for AR. When the testosterone level in the testis is high, there are no differences between testosterone and DHT (33). Testosterone concentrations in the testes of men $(340-2000 \mathrm{nM})$ are 25 to 125 fold greater than those in serum $(8.75-35 \mathrm{mM})$, similar to the situation in rodent testes (5). The testosterone level needed to maintain spermatogenesis is approximately $10-25 \%$ of the intratesticular testosterone level (34). AR signaling pathway in 


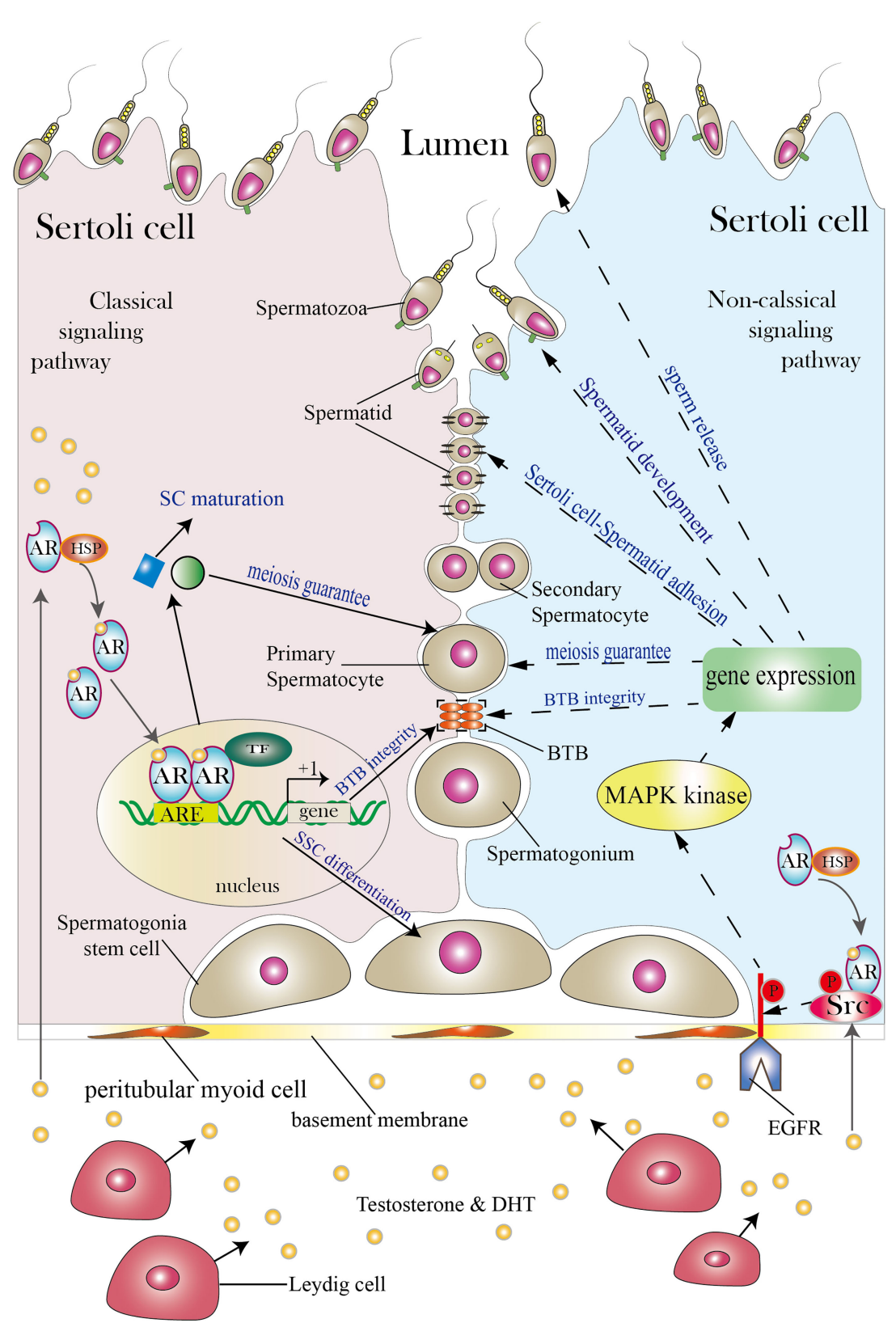

FIGURE 1 | Classical and non-classical AR signaling pathways in SCs. The SC shown on the left illustrates the classical signaling pathway, while the SC shown on the right illustrates the non-classical signaling pathway (both classical and non-classical signaling pathways can exist in a single SC; the two pathways are presented in separate cells for simplicity). Between the two neighboring SCs are germ cells (spermatogonia stem cells, spermatogonia, primary spermatocytes, secondary spermatocytes, spermatids and spermatozoa). SCs function as a nurse to take good care of normal spermatogenesis as spermatogonia stem cells develop into spermatozoa in the lumen. Androgen secreted by Leydig cells diffuses through the plasma membrane and binds to the AR complex in the cytoplasm to activate the classical signaling pathway. The AR then detaches from the HSP complex and enters the nucleus to form AR dimers. Dimerized ARs bind to the AREs of their target genes and thereby regulate their transcription. The classical signaling pathway can promote SC maturation, induce SSC differentiation, guarantee spermatocyte meiosis, and ensure BTB integrity. The non-classical signaling pathway begins with translocation of the AR from the cytoplasm to the plasma membrane. There, the AR interacts with Src and causes it to phosphorylate EGFR, and this in turn activates MAPK kinases to regulate targeted gene transcription. The non-classical signaling pathway can regulate processes including BTB integrity, spermatocyte meiosis, Sertoli cell-Spermatid adhesion, spermatid development and sperm release. The three orange ovals in the figure represent the BTB, and the two black lines represent cell-cell adhesion. TF is short for transcription factor. Areas for which controversy exists are not included in the figure but are discussed in the article. 
SCs can be divided into classical signaling pathway and nonclassical signaling pathway. The main differences between them lie in androgen binding location and response speed. Androgen binds to cytoplasmic AR in classical signaling pathway while in non-classical signaling pathway androgen binds to AR on plasma membrane. Compared with non-classical pathway, classical pathway requires more time to show transcriptional activity change after androgen binding to androgen receptor (35).

\subsection{Classical Signaling Pathway}

Before binding to androgen, AR in the cytoplasm binds to chaperones and cochaperones, such as heat shock proteins (HSP) HSP23, HSP40, HSP56, HSP70, HSP90 via its ligandbinding domain (17). When androgen in the cytoplasm binds to $\mathrm{AR}, \mathrm{AR}$ detaches from chaperone and cochaperone protein complexes and exposes its ligand-binding domain $(23,24,36)$. With the help of importins, the AR monomer transits into the nucleus, where $2 \mathrm{AR}$ monomers dimerize to create AR homodimers. AR homodimers then bind to androgen response elements (AREs) in the promoter regions of targeted genes to regulate their transcription $(37,38)$. In addition, activation function domain-1 presenting in AR dimer $\mathrm{N}$-terminal domain and activation function domain-2 presenting in its ligandbinding domain can recruit coactivators and corepressors that activate or repress targeted gene transcription activity (17). However, the binding sites for AR homodimers are not restricted to AREs; AR homodimers can also bind to some response elements for other transcription factor $(39,40)$. Notably, the classical AR signaling is relatively slow, usually 30-45 minutes is needed to induce activation or suppression of transcription, not considering the time required for protein synthesis and secretion (35).

\subsection{Non-Classical Signaling Pathway}

To date, three types of non-classical signaling pathway have been identified in the testis. Here is the first type, as well as the main type. When the intratesticular testosterone level is relatively low (10-250 nM), testosterone binds to the AR located in the cell membrane and activates the non-classical AR signaling pathway within 1 minute (41). In the TM4 Sertoli cell line, the transport of cytoplasmic ARs to the membrane is facilitated by caveolin-1 (42). Testosterone binds to membrane AR which then interacts with the SH3 domain of SRC proto-oncogene (Src). Src then phosphorylates the epidermal growth factor receptor (EGFR) which activates Ras kinase. This activates MAPK cascades (RasRaf-MEK-ERK). Phosphorylated ERK can phosphorylate ribosomal protein S6 kinase $\mathrm{A} 1\left(\mathrm{p} 90^{\mathrm{Rsk}}\right)$. Activated $\mathrm{p} 90^{\mathrm{Rsk}}$ translocate into nucleus, where it activates transcription factors such as CAMP-response element-binding protein (CREB), which binds to the cAMP-response element (CRE) of the targeted gene to regulate transcription $(41,43)$.

An in vitro study in which the TM4 cell line was exposed to testosterone levels of 10-100 nM demonstrated that testosterone can also activate a second non-classical signaling pathway, the phosphatidylinositol 3 kinase (PI3K)/Akt pathway, directly by activating the PI3K subunit $\mathrm{p} 85 \alpha$. Phosphorylated Akt can activate Src and this facilitates the translocation of cytoplasmic
AR to the plasma membrane (44). In addition to these in vitro studies, some in vivo studies also showed that testosterone can activate the non-classical signaling pathway in SCs $(35,45)$.

Another type of non-classical signaling pathway has only been found in immature Sertoli cells. Testosterone causes depolarization of Sertoli cells within thirty seconds due to closed $\mathrm{K}^{+}$ATP channel. This close is caused by $\mathrm{G}$ proteinmediated activation of phospholipase $\mathrm{C}$. This action results in a rapid influx of $\mathrm{Ca}^{2+}$ and the activation of signaling molecules (46-48).

Recently, Zrt- and Irt-like protein 9 (ZIP9), a novel membrane-bound androgen receptor unrelated to classic AR, was found in the 93RS2 Sertoli cell line which has no cytoplasmic AR. ZIP9 participates in the phosphorylation of CREB and ATF1 via ERK1/2 to induce the expression of claudin proteins that are components of BTB. The relationship between AR signaling and ZIP9 signaling remains to be researched in the future (49).

\section{ANDROGEN RECEPTOR SIGNALING PATHWAY IN SERTOLI CELLS CAN REGULATE SPERMATOGENESIS}

\subsection{Role of AR Mediated Signaling in Sertoli Cell Proliferation and Maturation}

SC proliferation occurs during fetal and early neonatal life in rodents, and in the fetal and peripubertal periods in higher primates when SCs undergo mitosis to increase their number (50). During the end of neonatal period or prepubertal period, SC proliferation stops. Then SCs maturation begins during puberty period, switching from an immature, proliferate state to a mature, non-proliferate state during which SCs establish BTB and acquire the ability to sustain spermatogenesis (51) AR signaling can participate in SC maturation process. Although it remains to be investigated if AR signaling in SCs influences SC proliferation, we still review studies in this field (Figure 2).

\subsubsection{Sertoli Cell Proliferation}

According to our knowledge, final testis size, number of germ cells and sperm output are closely connected to the number of SCs. This emphasizes the significance of SC proliferation. When porcine testis was treated with $\mathrm{AR}$ antagonists during postnatal proliferation, an increased number of SCs per testis was detected (52). However, SC numbers were increased in young ram lambs following prenatal exposure to testosterone (53). This is not contradictory, because administration of exogenous testosterone increases negative hypothalamic feedback and may reduce intratesticular testosterone levels, leading to decreased androgen signaling. However, when comparing the number of SCs per testis in Sertoli cell androgen receptor knockout (SCARKO) mice and androgen receptor knockout (ARKO) mice with the control group, researchers found that the SCARKO mice did not show significant differences compared to the controls, whereas the ARKO mice showed a significant decrease in SC number, indicating that in mice AR in SCs has little impact on SCs proliferation $(54,55)$. A similar 


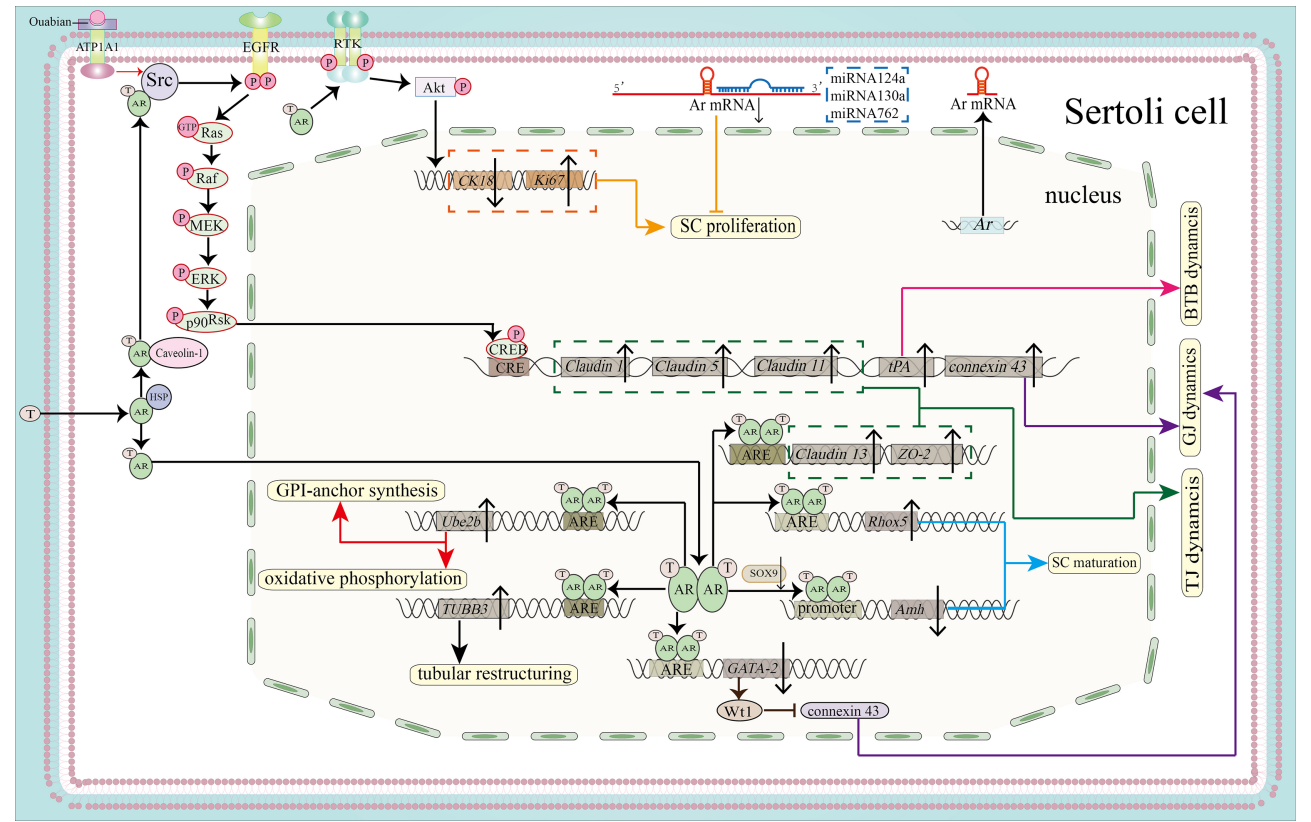

FIGURE 2 | Function of the AR signaling pathway in SC proliferation, maturation and BTB integrity. By activating the PI3K/Akt pathway, the AR can promote SC proliferation by downregulating CK18 and upregulating Ki67 (shown in orange). MicroRNAs, including miR124a, miRNA130a and miRNA762, can inhibit SC proliferation by binding to the 3'-UTR of Ar mRNA (also shown in orange). AR dimers can bind to the AREs of Rhox5 and Amh to promote the expression of Rhox5 and inhibit the expression of Amh, leading to SC maturation (blue). Binding to the ARE of TUBB3 induces tubular restructuring and achieve proper SC nuclei location, another process that is important in SC maturation. Ube2b, activated by the classical signaling pathway, is able to induce GPI-anchor synthesis and oxidative phosphorylation (shown in red). Both the classical and the non-classical signaling pathways are necessary for BTB integrity. The expression of Claudin 13 and tight junction protein 2 isoform 3 (ZO-2)is upregulated by classical AR signaling, together with upregulated expression of Claudin1, Claudin5, Claudin11 and tPA by non-classical signaling. These molecules regulate BTB dynamics (shown in pink) and TJ dynamics (shown in green). In addition, AR dimerization binds to the promoter of GATA-2 to inhibit its expression. GATA-2 can induce Wt1 expression, while Wt1 inhibits the protein expression level of connexin 43 to regulate GJ dynamics. Ouabain increases the expression of connexin 43 via the ATP1A1/Src/EGFR/ERK/CREB signaling pathway (shown in purple).

phenomenon was found when researchers used a testicular feminization mouse ( $\mathrm{Tfm}$ ) model that lacks functional AR in all cells (56). It is difficult to reconcile these results. We think that the expression of AR in SCs is undetectable or very weak during most of the periods in which these cells proliferate. While AR on other cell types such as peritubular myoid cells, which express $\mathrm{AR}$ at relatively high level, may contribute to SC proliferation. $\mathrm{Hu}$ et al. recently found that AR could interact directly with PI3K regulatory subunit $\mathrm{p} 85 \alpha$ to activate kinase Akt and that this represses the expression of Cytokeratin 18 (CK18) (a marker of immature and dysfunctional SCs) and induces the expression of Ki67 (a marker of SC proliferation), thereby preserving SC proliferation in mice (57). Since the experiments were conducted on mature mice, additional experiments on prepubertal mice are needed to test this result, although it is true that some immature SCs are present in mature mice. Considering these results as a whole, it seems that role of $\mathrm{AR}$ signaling in SC proliferation is species-specific and phasespecific. We suggest that future studies test different species with the aims of understanding and combining their AR expression patterns in SCs, their intratesticular androgen levels and their SC proliferation patterns to provide a better understanding of the role of AR in SC proliferation.

\subsubsection{Sertoli Cell Maturation}

Followed by cessation of SC proliferation comes to SC maturation. Around SC maturation, AR expression level is progressively upregulated until all SCs express AR (58). AR in SCs is key mediator for SC molecular and cytoskeleton maturation (59-61).

In molecular level, several molecules important for maturation are under AR signaling regulation (51) and the level of heterochromatin (62). Among them, Anti Mullerian hormone $(\mathrm{AMH})$ has been widely researched. $\mathrm{AMH}$ is crucial for fetal sex differentiation by regressing the Müllerian ducts in male $(13,63)$. Secreted by immature SCs, AMH has become a biomarker for testicular function in males during the prepubertal period which is tightly regulated by AR (64). During the postnatal period, AMH level can be maintained by androgen epi-testosterone through non-classical AR signaling pathway when intracellular AR level is very low (65). Other transcription factors, such as sex determining region Y-box 9 (SOX9), steroidogenic factor 1 (SF1) can bind to their own response elements to promote Amh transcription (66). Around the onset of puberty, upregulation of AR expression downregulates AMH expression by blocking SF1 binding to its response elements or interacting with $\mathrm{SF} 1$ response elements to 
prevent SF1from exerting a stimulatory effect on Amh transcription (67). An in vitro study using TM4 Sertoli cells and $\mathrm{C} 3 \mathrm{H} 10 \mathrm{~T} 1 / 2$ cell line demonstrated that AR could downregulate $\mathrm{AMH}$ expression by repressing SOX9, consistent with the findings in the azoospermia patients and mice in vivo (68).

Besides molecular level, AR signaling is necessary for SC cytoskeleton maturation. In SCARKO mice, relatively normal SCs nuclei were displaced from the basal basement and dispersed throughout the seminiferous tubules, probably resulting from the disrupted position of vimentin and the presence of thicker basal lamina, both of which participate in the linkage between nuclei and the cell membrane (69). Another group observed that SC nuclei formed one or two layered rings located in the center of tubule in mice in which AR function had been ablated (70). Suppressed expression of connexin $43(\mathrm{Cx} 43)$ in mice resulted in an intermediate state of SCs between proliferation and maturation, along with weaker AR immunostaining (71). The impaired SCs maturation observed in this model probably resulted from disrupted AR function. AR can also regulate microtubular composition and structure in SC so as to yield proper SC shape via Class III $\beta$ tubulin (TUBB3) in mice and rats through classical signaling pathway (72).

Premature expression of ARs in postnatal mouse SCs resulted in fewer SCs, although GCs development accelerated in a gainof-function mouse model (73). When the AR transgene was injected into a prenatal mouse model, precocious maturation of SCs occurred and limited the window for SC proliferation. The production of fewer SCs can lead to lower-than-normal sperm output (74).

\subsubsection{Factors Regulating Androgen Receptor Mediated Sertoli Cell Proliferation and Maturation}

Precise regulation of $\mathrm{Smad} 2 / \mathrm{Smad} 3$ is important both for SC proliferation and SC maturation (72). Type II A activin promotes immature testis growth along with timely appropriate AR expression via Smad3. The expression of Smad3 is then downregulated, and this is associated with cessation of SC proliferation and progression of the cells to terminal differentiation. AR activation can induce Smad2 transcription, which will further promote SC maturation through shifting from using Smad3 only to using both Smad 2 and Smad3 under activin A activation. In $\mathrm{Smad}^{-/-}$mice, delayed maturation of SCs was accompanied by reduced levels of AR and Smad2 (75).

In recent years, microRNAs (miRNAs) have been found to regulate SC proliferation and maturation. miR-124a binds to the 3'-UTR of Ar mRNA and downregulate AR expression, thereby inhibiting the proliferation of immature porcine SCs, while the coactivator really interesting new gene (RING) finger protein 4 (RNF4) binds to AR and promotes porcine SCs proliferation by elevating Proliferation cell nuclear antigen (a marker of cell proliferation) mRNA transcript levels (76). miR-762 promotes porcine SC maturation by inhibiting binding of RNF4 to AR (77). Moreover, miR-130a has been shown to inhibit AR expression, although its impact on SC proliferation and maturation remains to be elucidated (78). Additionally, the relationship of miR-133b (79) and miR-638 (80), which regulate $S C$ proliferation and maturation, to $A R$ remains to be investigated (Figure 2).

Importantly, the relationship between SC maturation and spermatogenesis is not well understood. We hypothesize that AR-regulated lipid metabolism in mature SCs can provide energy for spermatogenesis (81); for example, AR signaling in SCs induces the expression of ubiquitin-conjugating enzyme E2B (Ube2b) which regulates the expression of genes related to glycosylphosphatidylinositol (GPI)-anchor biosynthesis and oxidative phosphorylation (82). So does AR-regulated glucose uptake. The non-classical pathway participates in the regulation of glucose uptake via the cytochrome C oxidase (83). Also, BTB formed between SCs can facilitate normal spermatogenesis, as we will discuss later.

\subsection{Role of AR Mediated Signaling in Spermatogonia Stem Cells Self-Renewal and Differentiation}

Following the migration of gonocytes to the basement membrane and their differentiation into spermatogonia stem cells (5), SSCs are influenced by a network of signaling that can trigger SSC selfrenewal and differentiation. AR signaling in SCs has been found to participate in these two processes, probably promoting SSC differentiation and repressing SSC self-renewal, although it is not clear whether both of classical and non-classical signaling in SCs contribute to these processes in all species (Figure 3).

\subsubsection{Wnt5a}

Wnt5a, which refers to Wingless-type MMTV Integration Site Family Member $5 \mathrm{~A}$, is secreted by SCs in mice. Several studies found that Wnt5a expression is regulated by androgen and that it promotes SSCs self-renewal. Both in vitro and in vivo studies confirmed that Wnt5a can increase SSC self-renewal division after androgen blockage in mice SCs (84). In addition, Crespo et al. found that in zebrafish one androgen, 11-ketotestosterone (11-KT), indirectly inhibits SSC self-renewal by inhibiting prostaglandin E2 (PGE2) in SCs. Otherwise, PGE2 promotes SSC self-renewal by upregulating $W n t 5 a$ expression (85). However, more investigations should focus on the existence of AREs within the promoter of Wnt5a to confirm the exact signaling pathway in SCs through which androgen exerts its effects.

\subsubsection{Plzf}

Promyelocytic leukemia zinc finger (Plzf), a key transcription suppressor gene, has been characterized as a marker for undifferentiated SSCs in rodents (86) and primates (87). Plzf is important for SSC maintenance (45). Recently, in vivo and in vitro studies found that after activation of AR signaling in SCs, AR homodimer binds to the ARE region of GATA binding protein $2(G A T A-2)$ to inhibit its expression; this can further decrease WT1 transcription factor $(W t 1)$ expression since Wt1 expression requires binding of GATA-2to its promoter. Wt1 binds to $\beta 1$-integrin and increases its expression in SCs; $\beta 1$ integrin will interact with unknown molecules on the surface of 


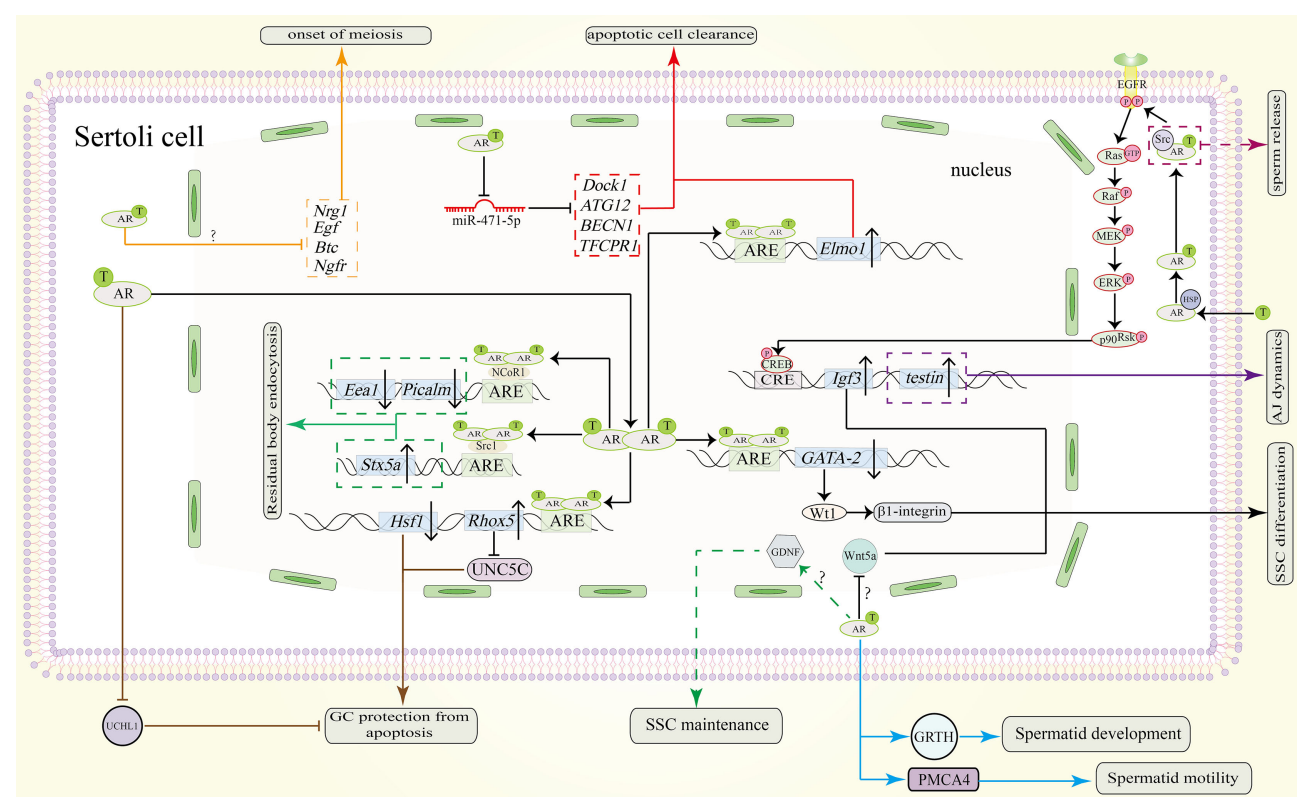

FIGURE 3 | Function of the AR signaling pathway in SCs in spermatogenesis. AR dimers in the nucleus can bind to the ARE of GATA-2 to inhibit its expression. Downregulated protein levels of GATA-2 downregulate Wt1 and $\beta 1$-integrin to promote SSC differentiation. The AR also promotes SSC differentiation by repressing Wnt5a. However, the precise pathway between AR and Wnt5a remains unknown. Through unknown pathway, AR allows SCs to secret GDNF for SSC maintenance (shown in green dotted line). Testosterone can also induce the expression of Igf3 through a non-classical signaling pathway to promote SSC differentiation. Through an unknown pathway, the AR represses the expression of Nrg1, Egf, Btc and Ngfr to induce the onset of meiosis (shown in orange). To protect GCs from apoptosis during meiosis, AR dimers bind to the AREs in the promoters of Rhox5 and Hsf1. Upregulated protein levels of Rhox5 repress Unc5c expression (shown in brown). Downregulation of Hsf1 can also protect GCs from apoptosis (shown in brown). Also, AR signaling in SCs can inhibit UCHL1 expression in spermatocytes to prevent them from apoptosis (shown in brown). In addition, the clearance of apoptotic cells is also important. Testosterone inhibits miR-471-5p and thereby upregulates the expression of Dock1, ATG12, BECN1 and TFCPR1, resulting in clearance by SCs (shown in red). Elmo1 upregulation by AR dimerization can also promote this process (shown in red). During spermiogenesis and spermiation, non-classical signaling induces the expression of testin, which is needed for proper adherence junctions (AJ) dynamics (purple solid line). The residual body from the maturing sperm will be absorbed by the concerted action of Stx5a, Picalm and Eea1 (shown in green). AR dimers also bind to the coactivator Src1 to induce the expression of Stx5a and to the corepressor NCoR1 to repress the expression of Picalm and Eea1. Spermatid development is also regulated by AR signaling. AR signaling in SCs induce GRTH and PMCA4 transcription and expression in spermatids which will promote their development and motility respectively (shown in blue line). Sperm release is facilitated by Src-mediated molecular processes (indicated by the purple dotted line). '?' indicates an unknown pathway.

SSCs, to induce Plzf expression. As a result, activation of classical AR signaling pathway can promote SSC differentiation by downregulating Plzf expression. We propose that the exact molecules that interact with $\beta 1$-integrin on SSC surface should be identified to determine a more concise relationship between SCs and SSCs (88).

\subsubsection{Other Factors}

In zebrafish, Insulin like growth factor 3 (Igf3) mRNA transcript level was found to be upregulated by androgen; this can promote SSC differentiation through non-classical signaling pathway (89). Reproductive homeobox 5 gene (Rhox5), which is directly regulated by classical AR pathway, also contributes to spermatogonia differentiation (90). Besides, in vitro study found that testosterone can increase Glial-derived neurotrophic factor (GDNF) secretion by Sertoli cell (91). Glial-derived neurotrophic factor secreted will promote Gdnf family receptor $\alpha 1$ and protooncogene Rearranged expression during Transfection expression for SSC self-renewal and maintenance (92).

\subsection{Role of AR Mediated Signaling in Spermatocytes Meiosis}

In diploid organisms, the sexual differentiation requires the production of haploid gametes via meiosis, a process in which two consecutive cell divisions occur after a round of DNA replication (93). During prophase I of meiosis, leptotene and zygotene stages produce the DNA double strand breaks (DSBs) needed for DNA recombination, along with the chiasmata required for homologous chromosome separation. Following the zygotene stage is pachytene stage, in which the synapsis is completed, and DNA combination is finished as well as DSBs repair. In SCs, the AR signaling pathway is believed to be important in these stages (94) (Figure 3).

Loss of spermatocytes and spermatids in rodents occurred as a result of decreased intratesticular testosterone level in hypophysectomy, gonadotropin-releasing hormone antagonist treatments and hypogonadal $(h p g)$ models (95). Above results indicate that testosterone mediated AR signaling is necessary for normal meiosis. Furthermore, inhibition of AR-Src interaction 
resulted in inactivation of non-classical signaling pathway in mice. Arrested meiosis was observed at the first spermatogenic wave (45). Moreover, in SCARKO mice where classical signaling pathway is blocked, De et al. observed loss of primary spermatocytes during stages VI-VII, a time when AR shows high protein expression level (96). These results suggest that both classical and non-classical AR signaling in SCs are indispensable for normal meiosis (Figure 3). In their attempt to determine the precise process that is regulated by AR signaling, Su et al. found that in SCARKO mice, meiosis arrest occurred in prophase I; cells failed to divide, and spermatocytes failed to acquire competence for the meiotic division phase (97). Although meiosis appeared to progress to a mid-pachytene-like cytological state, most germ cells stalled at an early-pachytene transcriptome stage (98). Precisely, meiosis arrest occurred between leptotene/zygotene to early-mid pachytene transition.

We conclude that there are two causes of meiotic arrest: chromosomal dysfunction and germ cell apoptosis.

\subsubsection{Chromosomal Dysfunction}

The fact that AR expression peaks at stages VI-VIII of meiosis, coinciding with the preleptotene and leptotene stages, suggests that the AR might mediate the preparation of SCs for chromosomal synapsis and recombination. Male germ cells can enter prophase I of meiosis normally and undergo normal DSBs formation in the absence of AR signaling (5). However, the problems happened on DSBs repair and chromosome synapsis. In SCARKO mice, chromosome synapsis was incomplete, as shown by the fact that Chen et al. detected a significantly larger number of univalent chromosomes in spermatocytes than in the control group. Additionally, RAD51 and DMC1 which are required for resolution of DSBs and homologous recombination, along with TEX15, BRCA1, BRCA2 and PALB2 which load RAD51 and DMC1 onto DSBs sites, showed decreased protein expression in SCARKO mice. Furthermore, activation of AR can negatively regulate Epidermal growth factors (EGFs), including Egf, betacellulin (Btc) and neuregulin 1 (Nrg1). These EGFs bind to their corresponding receptors (EGFR, ERBB4) on the surface of spermatocytes and stimulate the accumulation of above homologous recombination factors for appropriate prophase preparation (94). At the synaptonemal complex, nuclear autoantigenic sperm protein (NASP) inhibits formation of CDC2/cyclinB1 complex via HSP70-2 which are important for G2/M transition. NASP showed elevated expression after androgen manipulation. Other genes that show changes in transcript after androgen manipulation, such as Mapre1, Ruvbl1, Tuba1c, Tuba3a and Tubb2c, are related to spindle dynamics and the formation of dynactin complexes (99). Although fewer spermatocytes may gain competence to enter metaphase I, they cannot complete meiosis due to the lack of normal spindle dynamics, and this may account for the disruption in postmeiotic differentiation. More proteins account for chromosome synapsis and dynamics that is under AR regulation deserve to be confirmed to establish the AR downstream signaling network by taking advantage of the development of proteomics.

\subsubsection{Germ Cell Apoptosis}

GC apoptosis, especially apoptosis of spermatocytes, is another cause of meiotic arrest. This is not difficult to understand, since spermatocytes are cells that undergo meiosis. Through single cell transcript analysis technology, genes related to apoptosis have been identified. Aldh1a1, Igfbps, and mitochondrial membrane and oxidative phosphorylation transcripts were upregulated in SCARKO mice (98). Another group found that androgen deprivation led to a decreased expression of Aldh2, $\operatorname{Prdx} 6$ and Gstm5, which encode protectors of oxidative stress (99). Other genes related to androgen-dependent apoptosis, such as Diablo, $\mathrm{Cbl}, \mathrm{Hsfl}$ showed increased expression in mice after androgen deprivation or knocking out AR in SCs $(97,100)$. Hu et al. showed that Rhox5 can repress expression of Unc-5 Netrin Receptor C(UNC5C) which can promote spermatocyte apoptosis in vitro (101). Since Rhox 5 is regulated by classical signaling pathway $(90,102,103)$, it needs to be determined whether AR signaling represses UNC5C expression and thereby protects spermatocytes from apoptosis. Recently, Marina et al. found that ubiquitin carboxyl-terminal hydrolase L1(UCHL1) is negatively regulated by androgen. Decreased level of androgen leads to increased level of UCHL1 in spermatocytes, which will lead to deubiquitination of the pro-apoptotic factor p53. Deubiquitination of p53 triggers germ cell death (104). In addition, phagocytic clearance of apoptotic germ cells by SCs is vital for meiosis because phagocytosis of dying GCs provides lipid sources for SCs which will provide ATP for GCs development. Lower androgen increases the expression of miR471-5p, resulting in inhibition of Dock1, Tecpr1, Atg12 and Becn1. This leads to impaired LC3-associated phagocytosis. Besides, inhibition of Dock1, Rac1-GTPase in this model leads to disrupted engulfment of SCs (11). Both of these inhibitions impair clearance of apoptotic GCs by SCs. Another protein Elmo1, which is upregulated by classical AR signaling in vivo, participates in apoptotic germ cells clearance by SCs and functions downstream of Dock1 and Rac1-GTPase $(73,105)$.

Many of the transcription factors and regulators related to AR signaling that have been found are not mentioned here. These factors can participate in the regulation of meiosis. For additional information on these factors, please see Table 1. For additional genes that show changes in expression after androgen manipulation, please see the supplied references $(98,99,123)$.

Based on the evidences presented above, we propose the reasons for meiotic arrest when AR signaling in SC is impaired. Chromosomal dysfunction or breakage can induce oxidative stress that cannot be repressed because of the decreased level of oxidative stress protectors. This leads to apoptosis of some spermatocytes. The presence of increased number of apoptotic cells, the failure to clear apoptotic cells combined with DNA damage trigger the inner meiotic checkpoint and cause meiosis to halt in prophase I. Future studies might focus on the roles of genes related to AR signaling that have been mined through mRNA transcript analysis in meiosis and attempt to determine whether they play permissive roles or instructive roles for meiosis. 
TABLE 1 | Transcription regulators, upstream regulators and downstream regulators of Androgen receptor signaling during spermatogenesis.

\begin{tabular}{|c|c|c|c|c|}
\hline \multicolumn{2}{|l|}{ Regulators } & \multirow[t]{2}{*}{ species } & \multirow[t]{2}{*}{ function } & \multirow[t]{2}{*}{ reference } \\
\hline \multirow{2}{*}{\multicolumn{3}{|c|}{ Coactivator }} & & \\
\hline & ARID4B/4A & mice & BTB integrity & \\
\hline & & & Timely SC maturation & $(106,107)$ \\
\hline & & & Normal meiosis & \\
\hline & & & Normal Rhox5 function & \\
\hline & & & Post-meiotic differentiation & \\
\hline & ARIP4 & rats & Normal Rhox5 function & $(108)$ \\
\hline & & & Germ cells proliferation & \\
\hline & SRC-2 & human & Sustainable production of spermatozoa & $(109)$ \\
\hline & TRAM-1 & human & Regulation of transcription & $(110)$ \\
\hline & PSPC1 & mice & Promote AR transactivation & $(111)$ \\
\hline & NONO & mice & Promote AR transactivation & $(111)$ \\
\hline & SFPQ & mice & Promote AR transactivation & $(111)$ \\
\hline & SRC-1 & rats & Promote residual body absorption & $(112)$ \\
\hline \multicolumn{5}{|l|}{ Corepressor } \\
\hline & DjA1 & mice & Inhibit spermatocyte death & $(113)$ \\
\hline & & & Promote round spermatid differentiation & \\
\hline & & & Maintain adhesion junctions & \\
\hline & $\mathrm{HBO}-1$ & human & Participate DNA replication & $(109)$ \\
\hline & & & Initiate and maintain spermatogenesis & \\
\hline & NCOR1 & rats & Promote residual body absorption & $(112)$ \\
\hline \multicolumn{5}{|c|}{ Upstream regulators } \\
\hline & P110ßPI3-kinase & mice & Spermatocyte differentiation & $(114)$ \\
\hline & Tzfp & mice & Normal cross-over through pachynema & $(115)$ \\
\hline & & & Germ cell formation & \\
\hline & & & Repress AR signaling & \\
\hline & $N F-\kappa B$ & rats & Activate transcription of $\mathrm{AR}$ & $(116)$ \\
\hline & LncNONO-AS & goats & Activate AR expression via NONO & $(117)$ \\
\hline \multicolumn{5}{|c|}{ Downstream regulators } \\
\hline & Rhox5 & mice & Enter prophase during prepuberty & $(101,102)$ \\
\hline & & & Facilitate the first step of meiosis during puberty & \\
\hline & & & Sperm release & \\
\hline & & & BTB remodeling & \\
\hline & FGF2 & mice & Trigger spermatogonia proliferation and differentiation & $(118)$ \\
\hline & & & Meiosis initiation & \\
\hline & Aard & mice & Normal spermatogenesis & $(119)$ \\
\hline & & & Regulate transcription activity & \\
\hline & $\mathrm{Cbl}$ & rats & Activate androgen-dependent & $(120)$ \\
\hline & PMCA4 & mice & Movement and motility of sperm & $(121)$ \\
\hline & Hsf1 & mice & Protect immature gem cells & $(100)$ \\
\hline & Ube2b & mice & glycosylphosphatidylinositol (GPI)-anchor biosynthesis and oxidative phosphorylation & $(82)$ \\
\hline & Elmo1 & mice & Sertoli cell mediated phagocytic clearance of apoptotic germ cells & $(105)$ \\
\hline & Spinlw1 & rats & Sperm motility & $(122)$ \\
\hline & testin & mice & Adhesion junction dynamics & $(113)$ \\
\hline
\end{tabular}

\subsection{Role of AR Mediated Signaling in Maintenance of Blood-Testis Barrier}

SCs in mammalian testis can divide the seminiferous epithelium into basal and adluminal compartments through the construction of BTB. During stages VII-VIII of seminiferous epithelium cycle when the AR expression level peaks in rodents, BTB undergoes restructuring to facilitate the translocation of preleptotene spermatocytes from the basal area to the apical area where they will complete the entire processes of meiosis and post-meiotic processes. This transition, facilitated by testosterone, requires breakage of the 'old' BTB before preleptotene spermatocytes and formation of 'new' BTB after preleptotene spermatocytes entering into adluminal compartment $(97,124)$. Moreover, BTB shields haploid germ cells from recognition by the innate immune system; and this is why we also call it 'immune barrier' (125). BTB includes many types of junctions: tight junctions (TJs), gap junctions (GJs), desmosomes, basal ectoplasmic specialization (ES). These junctions undergo dynamic changes to fulfill their roles. Exposure of SC cultures to adenovirus constructs expressing inhibitors of either classical or non-classical AR signaling pathway led to increased permeability of BTB, suggesting that both classical and non-classical signaling pathway are important for BTB integrity, probably through regulating junction proteins $(45,126)$. (Figure 2).

\subsubsection{Tight Junction}

Classical signaling pathway regulates proper tight junction dynamic. In mouse models with mutations in exon1 of AR, increased permeability of BTB was observed $(124,127)$. 
Although the BTB appears to be present in this model under microscopic examination, it is incomplete as we found biotin enter into adluminal area with the help of biotin tracer (127). Reversibly, BTB were strengthened after testosterone treatment of an SC culture system with disrupted AR function (128). To further investigate the molecular basis of these effects, microarray analysis was used to identify the genes that may be involved. The mRNA transcript level of tight junction protein including Claudin 3, Claudin 11, Claudin 13 were all downregulated while Occludin and Claudin 26 showed elevated transcript levels after ablation of exon1 of AR in mice (129). Among them, Claudin 3 which is not essential for fertility, is expressed in the newly formed BTB after preleptotene spermatocytes migrate past the old BTB (127). Claudin 13 shows a similar expression pattern to Claudin 3. CHIP-seq assays found putative AREs in the promoter regions of Claudin 13 and tight junction protein 2 isoform 3, indicating a potential classical signaling regulation pattern. In contrast to Claudin 3, Claudin 11 preserves its expression throughout the seminiferous cycle. Besides, membrane-associated GUK family of proteins including tight junction protein 1, tight junction protein 2 isoform 1, tight junction protein 2 isoform 2, and tight junction protein 2 isoform 3, can function as a bridge that links tight junction proteins to the cytoskeleton like actin filaments. Their mRNA transcripts were found to be downregulated in mouse SCs after ablation of AR (129-131). What's more, it was found that tight junction proteins can enter the nuclei of SCs and regulate their own transcription (132), indicating possible tight junction proteins compensatory effects in $\mathrm{Cldn} 3^{-/-}$mutant mice.

Apart from its directly regulation of TJ proteins, non-classical signaling can regulate $\mathrm{TJ}$ proteins via tissue type plasminogen activator (tPA) during stages VII-VIII of spermatogenesis when BTB undergoes restructuring (133). We also know that tPA is involved in BTB degradation (134), indicating a potential role of tPA in BTB dynamics. Moreover, Dietze et al. and Bulldan et al. found that Claudin 1, Claudin 5 and Claudin 11 protein levels were upregulated by CREB protein $(49,135,136)$. These results further support the idea that non-classical androgen signaling can maintain BTB integrity by regulating tight junction dynamics.

Besides, in heat-treated monkey testes, $\mathrm{AR}$ regulates reversible changes in BTB integrity via Par complex (Par6Par3, Par6-aPKC, and Par6-Cdc42) targeting TJ proteins (ZO1 and occludin) and basal ES proteins (N-cadherin, E-cadherin, a-catenin, $\beta$-catenin, and $\gamma$-catenin) (137).

Based on the results described above, we hypothesize that although the transition of preleptotene spermatocytes into adluminal compartment is not blocked when AR signaling in SC is prevented, the amount of claudin available for remodeling BTB (Claudin 3, Claudin 11, Claudin 13) is insufficient under these conditions. Besides, the downregulated tight junction proteins are not sufficient to enter the nucleus and increase their own transcription, let alone to recruit more claudins to the BTB. While Occludin and Claudin26 show relatively upregulated mRNA transcript levels, this is not enough to compensate for the loss of other tight junction proteins. Thus, humoral immunity against self-antigens is mounted, resulting in disruption of normal spermatogenesis.

\subsubsection{Gap Junction}

Connexin 43 (Cx43), one gap junction protein, also under $\mathrm{AR}$ regulation as shown by its reduced mRNA transcript levels and protein expression levels in adult pig testes treated with flutamide, an anti-androgen (138). Interestingly, we also found weak AR immunostaining and partial disruption of AR signaling in SCs in Sertoli cell specific knock-out of connexin 43 mice (71). $\mathrm{Xia}$ et al. found that androgen can regulate the expression of $\mathrm{Wt} 1$ indirectly by inhibiting GATA-2expression. Androgen inhibits GATA-2 expression through the classical pathway. Wt1 can bind to the promoter of $\mathrm{Cx} 43$ and inhibit its expression, indicating that androgen can promote $\mathrm{Cx} 43$ expression by downregulating GATA-2 and Wt1 (139). What's more, ouabain binding to its receptor ATP1A1can upregulate $\mathrm{Cx} 43$ expression via nonclassical signaling pathway in vivo (140). The relationship between $\mathrm{Cx} 43$ and $\mathrm{AR}$ deserves further investigation. It remains to be determined whether reversing one of them (Cx43 or AR) can restore the other to normal level in human and correct impaired spermatogenesis, though it is possible that treating hpg mice with DHT can restore the expression and localization of $\mathrm{Cx} 43$ to the BTB (141).

\subsubsection{Blood-Testis Barrier Renewal}

The endocytosis of old BTB proteins for renewal is also important for BTB integrity (142). Testosterone can promote the endocytosed occludin to the BTB location through recycling pathway (124). Other cells such as Madin-Darby canine kidney cells and epithelial cells can internalize occluding and claudin via clathrin- and caveolin-mediated pathways (143, 144). Coincidentally, $\mathrm{Su}$ et al. found that testosterone increases levels of clathrin and caveolin-1 in SCs (145), this suggests that AR signaling may participate in tight junction protein endocytosis for renewal via the clathrin and caveolin-1 pathways. This possibility needs further investigation.

Since AR signaling is important for BTB integrity, what will happen if $A R$ is overexpressed under normal conditions? The influence of a tighter BTB on spermatogenesis remains unknown. We suggest an in vitro $\mathrm{AR}$ overexpression experiment to answer this question. Recently, in muscle cells, it was found that AR can participate in IGF-1/IGF-1R-PI3K/AktmTOR pathway (146). We also know that mTOR signaling can regulate BTB dynamic by balancing the levels of F-actin binding proteins epidermal growth factor receptor pathway substrate 8 and actin related protein 3 (147). Therefore, we suggest investigation into crosstalk between AR and mTOR pathway and its downstream molecules related to actin-binding proteins in germ cell lines.

\subsection{Role of AR Mediated Signaling in Sertoli Cell - Spermatid Adhesion and Sperm Release}

Before spermiogenesis occurs, round spermatids are linked to SCs by desmosomes. When the cycle of seminiferous epithelium 
enters into stage VII, the round spermatids begin to elongate accompanied by the replacement of desmosome anchors with new specialized adhering proteins. We call the structure formed in this way as apical ectoplasmic specialization (ES). The proteins that form ES disassemble before sperm release during stage VIII. The complexes connecting SC and elongated spermatids are tubulobulbar complex and the focal adhesionrelated disengagement complex. AR signaling pathway is important in two processes during spermiogenesis and final spermiation: Sertoli cell - Spermatid adhesion and sperm release (Figures 2, 3).

The importance of AR signaling in Sertoli cell - Spermatid adhesion and sperm release is elucidated by two in vivo model. First, in rats that received subdermal testosterone and oestradiol (TE) implants to lower the intratesticular testosterone level, researchers found loss of stage VIII and late spermatids (148, 149). Additionally, hypomorphic SCARKO mice displayed premature release of round spermatids as well as blockage of terminal differentiation and release of elongated spermatids. The unreleased mature spermatids were degenerated or phagocytized by SCs $(149,150)$.

\subsubsection{Sertoli Cell - Spermatid Adhesion}

The molecular mechanism through which Sertoli cell Spermatid adhesion occurs has been elucidated. Based on experiments in which adenovirus constructs were used to express different AR mutants that impair the classical or nonclassical pathways and on other experiments in which inhibitors of ERK kinase and Src kinase were added to an SCGC coculture system, it is proposed by study that non-classical AR signaling pathway contributes dominantly to Sertoli cellSpermatid adhesion, while activation of the classical AR signaling pathway is not sufficient to permit Spermatids binding to SCs (151). Testosterone can promote the attachment of spermatids to SCs in Sertoli cell -Spermatid coculture system by activation ERK and Src, which belong to the non-classical signaling pathway (152). Terada et al. found that testin, which can be induced by non-classical signaling pathway, is important for Sertoli cell - Spermatid adhesion. Overexpression of testin can block spermatid differentiation, probably due to excessive adhesion to SCs (113). However, an in vivo study adopting TE implants brought about not only the loss of spermatids but also the activation of ERK before sperm release, along with breakage association of $\mathrm{N}$-cadherin and $\beta$ catenin indicating disruption of ES (153). This result seems contradictory to in vitro study. One possible reason maybe that the formation of ES requires ERK activation only at the beginning of formation rather than during the entire process.

\subsubsection{Sperm Release}

Round spermatids develop into elongated sperm before final releasing.

Gonadotropin Regulated Testicular Helicase (GRTH/ DDX25) is significant in this process, mainly by participating on the nuclear export and transport of specific mRNAs as well as the structural integrity of Chromatoid Bodies of round spermatids (154). As an RNA helicase and only DEAD-box family member regulated by androgen in spermatids, GRTH/ DDX25 transcription in spermatid is regulated by AR signaling pathway in Sertoli cells through a paracrine fashion. Germ cell nuclear factor (GCNF) in spermatids can promote GRTH/ DDX25 transcription and expression in response to androgen regulation (155-158). However, the signal relayed to spermatids remains to be further elucidated.

Before releasing sperm, SCs endocytose the residual body from maturing sperm. Kumar et al. found that AR dimerization can recruit corepressor nuclear receptor corepressor 1 (NCoR1) to the ARE of phosphatidylinositol binding clathrin assembly protein (Picalm) and early endosome antigen 1 (Eea1) and thereby inhibit their expression. Coactivator steroid receptor coactivator-1 (Src1) can be recruited to ARE of syntaxin 5 (Stx 5a) and induce its expression $(112,159,160)$. Since the products of these 3 genes are located around tubule bulbar complexes and participate in endocytosis and intracellular transport, it is possible that they are involved in residual body absorption.

Activation of Src is important for sperm release $(161,162)$. The injection of Src inhibitor into rat testis can block the release of elongating spermatids, while injection of an ERK inhibitor has little effect on sperm release $(152,163)$. Additionally, O'Donnell et al. pointed out that the disengagement complex, including $\alpha 6 \beta 1$ integrin which associates with Src, and tyrosine-phosphorylated focal adhesion kinase (FAK), remains associated with sperm that fail to be released. Both Src and FAK can be phosphorylated on activation of non-classical androgen signaling (149). Further study confirmed that activated non-classical signaling target Src is near the head of sperm to be released (164).

Also, sperm motility is significant during sperm release. Located in elongated spermatids, ATPase $\mathrm{Ca}^{++}$transporting plasma membrane 4 (PMCA4) is critical for sperm motility (165). Recently, it was found that PMCA4 is positively regulated by AR signaling in SCs both in vitro and in vivo (121).

In a summary, non-classical AR signaling promotes Sertoli cell - Spermatid adhesion by activating both ERK and Src while promoting sperm release by activating Src. Considering the above study, future studies might focus on achieving a deeper understanding of the different effects of Src to immature spermatid and mature spermatid as well as the impact of both ERK and Src to other kinds of proteins in apical ES.

\section{DISCUSSION ON ANDROGEN INSENSITIVITY SYNDROME: PRESENT ADVANCES AND FUTURE THERAPIES}

Infertility is an emerging worldwide public health issue. Approximately $20-70 \%$ of cases are due to male infertility (166). For most men suffering from infertility, the primary cause is low quality and low quantity of sperm (167). Hormones, including androgens, are necessary for spermatogenesis. We have reviewed AR signaling in SCs above. Clinical mutations in androgen receptor can cause reproductive diseases such as Androgen insensitivity syndrome, Sertoli cell-only syndrome and 
Obstructive azoospermia. Here we will focus on androgen insensitivity syndrome, which is closely related to AR mutations in SCs.

Androgen insensitivity syndrome (AIS) is an X-linked recessive disorder of sex development in patients with the 46, XY karyotype (168). According to the National Institutes of health, approximately 2-5 in 100000 people may have AIS. The biochemical mechanism behind AIS is the inability of cells expressing AR to respond to androgen, leading to incomplete or absent genital virilization of the 46, XY embryo (169). Specifically, the mutations in AR result in disrupted capacity of binding to testosterone or DHT, leading to impaired differentiation of the Wolffian ducts and impaired virilization of the external male genitalia respectively (170). At present, AIS is classified into two categories, AIS type I and AIS type II. In AIS type I, mutations exist in AR itself; this type of AIS can be further classified into complete AIS (CAIS), partial AIS (PAIS) and mild AIS (MAIS) according to the AR mutation level, while mutations in AIS type II occur in molecules downstream of AR rather than in AR itself (171). The clinical phenotype of CAIS is characterized by an external female phenotype with undescended testes (172), PAIS leads to different ranges of hypospadias and ambiguous genitalia (173) and individuals with MAIS display a male phenotype, sometimes with gynecomastia, and insufficient sperm production (174). Recent years, studies and many case reports have revealed different AR mutations in patients with AIS. Mutations found up to now include gene deletion, mutations in transactivation domain, mutations in the DNA binding domain, mutations in the ligand binding domain. (For additional information, please see review (175)) In addition, even individuals without a mutation in the AR gene can show an AISlike syndrome, indicating that mutations may have occurred somewhere else (176).

Currently, researches on AIS focus mainly on recording patient phenotypes and detecting AR mutations through sequencing of AR gene. Various AR mutations have been found to date (177). Inadequate research on associated gene expression patterns presents much difficulties for the development of therapies, especially for type II AIS. In addition, few studies have used testicular histology to examine the effects of AR mutations on testis. Recently, one CAIS patient showed unusually high level of AMH and SOX9, accompanied by immature SCs, a phenomenon that has been linked in a mouse model to the AR/SOX9/AMH pathway discussed above (178). AMH, along with Inhibin B, which may have positive or inverse correlation with $\mathrm{AMH}$, is thought to be appealing subject for study by endocrinologists because patients with androgen insensitivity or defects in androgen synthesis have normal or high levels of AMH (179).

Notably, a high level of estrogen was found in patients with CAIS, and this may explain the development of breast cancer in some of these patients. Supporting this idea, it is known that testosterone can be converted into estrogen via aromatase and luteinizing hormone can stimulate testicular estrogen synthesis. Researchers have found high levels of luteinizing hormone and testosterone in AIS patients $(168,175,180)$. Interestingly, apolipoprotein D (APOD), which is induced by DHT, is a potential candidate marker for the detection of AIS, especially for type II AIS. Treating type II AIS patients with DHT can induce endogenous APOD expression but the level of APOD is below the calculated cut-off (181). Other molecular pathways downstream of $\mathrm{AR}$ in AIS patients are remaining to be elucidated. One question arises for our molecular research. Although mice and rats have high homology with humans, some phenotypes in AIS patients cannot be reproduced in mouse or rat models. Although this is a significant barrier in our research, we should not be pessimistic. In a comparison of control males and CAIS females, significant differences in the transcription levels of 612 genes were found at the cellular level, suggesting that androgens may play a role in transcriptome regulation in humans (182). We are pleased to see that AR can regulate the transcriptome level in mouse models (98); this observation can guide us to investigate genes with known function in mouse models in our clinical diagnosis and to research genes that show no overlap between two species in mice to determine their function.

In summary, our opinions are that the diagnosis for AIS should combine power from different fields of study. For geneticists, family history is recommended to record for prenatal diagnosis, along with determining the patient's karyotype after birth (183). Some important biomarkers, such as $\mathrm{AMH}$, estrogen, luteinizing hormone and testosterone should be measured at birth or at puberty to distinguish AIS from androgen synthesis deficiency by endocrinologists. Cytologists and histologists use fine needle aspiration cytology (184) and histopathology to examine the state of SCs and the testicular lumen, and the results obtained may be compared with results obtained from patients with other syndromes like, such as Sertoli cell-only syndrome or nonobstructive azoospermia, possibly benefiting from therapies for those diseases. Finding associated genes and impaired signaling pathway are tasks for molecular biologists. Combined efforts are powerful.

At present, the most common treatment for CAIS is gonadectomy in early adulthood. There are two reasons for this: 1) an undescended testis has an increased risk of malignant transformation after puberty; and 2) testosterone produced by the testis can be converted to estrogen, so puberty will occur naturally $(185,186)$. Besides, treatment for PAIS vary between different patients. Treatments currently include androgen supplementation at puberty, surgeries to repair hypospadias and bring undescended testes into the scrotum. Personal treatment should combine diagnosis, sex assignment and biochemical examination (187). Previous study using AR transgene model restored the impaired spermatogenesis in SC AR mutant mice (188). Whether transfection of AR constructs into human SCs can benefit AIS patients remains to be elucidated.

Moreover, the job of a doctor is not only to treat patients physically, but also to treat them psychologically. Helping AIS patients overcome their psychological disorders and live a normal life without discrimination is a responsible behavior for doctors and for society as a whole.

\section{CONCLUSION AND PERSPECTIVE}

Both classical and non-classical androgen receptor signaling pathway are essential for spermatogenesis. These two pathways 
not only regulate genomic action in Sertoli cells but also influence germ cells between Sertoli cells through paracrine action. Sertoli cells are expected to be a new therapeutic target. However, rare studies focus on the relationship between androgen receptor signaling pathway, Sertoli cell and clinical diseases. The transgenic model developed recently which is able to activate only classical or non-classical signaling pathway, allows us to screen more genes related to androgen receptor signaling pathway. These genes are helpful for us to develop therapies for treating infertility. Moreover, spermatogonia transplantation is a method to inject spermatogonia into seminiferous tubule lumen and promote spermatogonia to form colonization at basement area, which may cure fertility fundamentally. The problem about making spermatogonia migrating from adluminal area to basement area may be solved by androgen therapies because lowering testicular testosterone level can open BTB reversibly.

\section{REFERENCES}

1. Agarwal A, Baskaran S, Parekh N, Cho C-L, Henkel R, Vij S, et al. Male Infertility. Lancet (2021) 397(10271):319-33. doi: 10.1016/s0140-6736(20) 32667-2

2. Sharlip ID, Jarow JP, Belker AM, Lipshultz LI, Sigman M, Thomas AJ, et al. Best Practice Policies for Male Infertility. Fertil Steril (2002) 77(5):873-82. doi: 10.1016/s0015-0282(02)03105-9

3. Practice Committee of the American Society for Reproductive Medicine. Diagnostic Evaluation of the Infertile Male: A Committee Opinion. Fertil Steril (2015) 103(3):e18-25. doi: 10.1016/j.fertnstert.2014.12.103

4. de Kretser DM, Loveland KL, Meinhardt A, Simorangkir D, Wreford N. Spermatogenesis. Hum Reprod (Oxf Eng) (1998) 13 Suppl 1:1-8. doi: 10.1093/humrep/13.suppl_1.1

5. Walker WH. Androgen Actions in the Testis and the Regulation of Spermatogenesis. Adv Exp Med Biol (2021) 1288:175-203. doi: 10.1007/ 978-3-030-77779-1_9

6. Iliadou PK, Tsametis C, Kaprara A, Papadimas I, Goulis DG. The Sertoli Cell: Novel Clinical Potentiality. Hormones (Athens Greece) (2015) 14 (4):504-14. doi: 10.14310/horm.2002.1648

7. Crisóstomo L, Alves MG, Gorga A, Sousa M, Riera MF, Galardo MN, et al. Molecular Mechanisms and Signaling Pathways Involved in the Nutritional Support of Spermatogenesis by Sertoli Cells. Methods Mol Biol (Clifton NJ) (2018) 1748:129-55. doi: 10.1007/978-1-4939-7698-0_11

8. Ma W, Li S, Ma S, Jia L, Zhang F, Zhang Y, et al. Zika Virus Causes Testis Damage and Leads to Male Infertility in Mice. Cell (2016) 167(6):151124.e10. doi: 10.1016/j.cell.2016.11.016

9. Kaur G, Thompson LA, Dufour JM. Sertoli Cells-Immunological Sentinels of Spermatogenesis. Semin Cell Dev Biol (2014) 30:36-44. doi: 10.1016/ j.semcdb.2014.02.011

10. Wong CH, Xia W, Lee NP, Mruk DD, Lee WM, Cheng CY. Regulation of Ectoplasmic Specialization Dynamics in the Seminiferous Epithelium by Focal Adhesion-Associated Proteins in Testosterone-Suppressed Rat Testes. Endocrinology (2005) 146(3):1192-204. doi: 10.1210/en.2004-1275

11. Panneerdoss S, Viswanadhapalli S, Abdelfattah N, Onyeagucha BC, Timilsina S, Mohammad TA, et al. Cross-Talk Between miR-471-5p and Autophagy Component Proteins Regulates LC3-Associated Phagocytosis (LAP) of Apoptotic Germ Cells. Nat Commun (2017) 8(1):598. doi: 10.1038/ s41467-017-00590-9

12. Petersen C, Soder O. The Sertoli Cell-a Hormonal Target and 'Super' Nurse for Germ Cells That Determines Testicular Size. Horm Res (2006) 66(4):15361. doi: $10.1159 / 000094142$

13. Boukari K, Meduri G, Brailly-Tabard S, Guibourdenche J, Ciampi ML, Massin N, et al. Lack of Androgen Receptor Expression in Sertoli Cells Accounts for the Absence of Anti-Mullerian Hormone Repression During

\section{AUTHOR CONTRIBUTIONS}

J-MW, Z-FL, and W-XY conceived of and authored the paper. All authors contributed to the article and approved the submitted version.

\section{FUNDING}

This work was supported in part by National Natural Science Foundation of China (No 32072954).

\section{ACKNOWLEDGMENTS}

The authors want to show their appreciation to all members of the Sperm Laboratory in Zhejiang University for their support, encouragement, and assistance.

Early Human Testis Development. J Clin Endocrinol Metab (2009) 94 (5):1818-25. doi: 10.1210/jc.2008-1909

14. Buzek SW, Sanborn BM. Increase in Testicular Androgen Receptor During Sexual Maturation in the Rat. Biol Reprod (1988) 39(1):39-49. doi: 10.1095/ biolreprod39.1.39

15. Callewaert L, Van Tilborgh N, Claessens F. Interplay Between Two Hormone-Independent Activation Domains in the Androgen Receptor. Cancer Res (2006) 66(1):543-53. doi: 10.1158/0008-5472.Can-05-2389

16. Soffientini U, Rebourcet D, Abel MH, Lee S, Hamilton G, Fowler PA, et al Identification of Sertoli Cell-Specific Transcripts in the Mouse Testis and the Role of FSH and Androgen in the Control of Sertoli Cell Activity. BMC Genomics (2017) 18(1):972. doi: 10.1186/s12864-017-4357-3

17. Chaturvedi AP, Dehm SM. Androgen Receptor Dependence. Adv Exp Med Biol (2019) 1210:333-50. doi: 10.1007/978-3-030-32656-2_15

18. Rey RA. The Role of Androgen Signaling in Male Sexual Development at Puberty. Endocrinology (2021) 162(2):1-16. doi: 10.1210/endocr/bqaa215

19. Shaffer PL, Jivan A, Dollins DE, Claessens F, Gewirth DT. Structural Basis of Androgen Receptor Binding to Selective Androgen Response Elements. Proc Natl Acad Sci USA (2004) 101(14):4758-63. doi: 10.1073/pnas.0401123101

20. Claessens F, Alen P, Devos A, Peeters B, Verhoeven G, Rombauts W. The Androgen-Specific Probasin Response Element 2 Interacts Differentially With Androgen and Glucocorticoid Receptors. J Biol Chem (1996) 271 (32):19013-6. doi: 10.1074/jbc.271.32.19013

21. Verrijdt G, Schoenmakers E, Haelens A, Peeters B, Verhoeven G, Rombauts W, et al. Change of Specificity Mutations in Androgen-Selective Enhancers. Evidence for a Role of Differential DNA Binding by the Androgen Receptor. J Biol Chem (2000) 275(16):12298-305. doi: 10.1074/jbc.275.16.12298

22. Schoenmakers E, Verrijdt G, Peeters B, Verhoeven G, Rombauts W, Claessens F. Differences in DNA Binding Characteristics of the Androgen and Glucocorticoid Receptors can Determine Hormone-Specific Responses J Biol Chem (2000) 275(16):12290-7. doi: 10.1074/jbc.275.16.12290

23. Ni L, Llewellyn R, Kesler CT, Kelley JB, Spencer A, Snow CJ, et al. Androgen Induces a Switch From Cytoplasmic Retention to Nuclear Import of the Androgen Receptor. Mol Cell Biol (2013) 33(24):4766-78. doi: 10.1128/MCB.00647-13

24. Haelens A, Tanner T, Denayer S, Callewaert L, Claessens F. The Hinge Region Regulates DNA Binding, Nuclear Translocation, and Transactivation of the Androgen Receptor. Cancer Res (2007) 67(9):4514-23. doi: 10.1158/ 0008-5472.CAN-06-1701

25. Clinckemalie L, Vanderschueren D, Boonen S, Claessens F. The Hinge Region in Androgen Receptor Control. Mol Cell Endocrinol (2012) 358(1):18. doi: 10.1016/j.mce.2012.02.019

26. Matias PM, Donner P, Coelho R, Thomaz M, Peixoto C, Macedo S, et al. Structural Evidence for Ligand Specificity in the Binding Domain of the Human Androgen Receptor. Implications for Pathogenic Gene Mutations. J Biol Chem (2000) 275(34):26164-71. doi: 10.1074/jbc.M004571200 
27. Tan MH, Li J, Xu HE, Melcher K, Yong EL. Androgen Receptor: Structure, Role in Prostate Cancer and Drug Discovery. Acta Pharmacol Sin (2015) 36 (1):3-23. doi: 10.1038/aps.2014.18

28. Bremner WJ, Millar MR, Sharpe RM, Saunders PT. Immunohistochemical Localization of Androgen Receptors in the Rat Testis: Evidence for StageDependent Expression and Regulation by Androgens. Endocrinology (1994) 135(3):1227-34. doi: 10.1210/endo.135.3.8070367

29. Suárez-Quian CA, Martínez-García F, Nistal M, Regadera J. Androgen Receptor Distribution in Adult Human Testis. J Clin Endocrinol Metab (1999) 84(1):350-8. doi: 10.1210/jcem.84.1.5410

30. Smith LB, Walker WH. The Regulation of Spermatogenesis by Androgens. Semin Cell Dev Biol (2014) 30:2-13. doi: 10.1016/j.semcdb.2014.02.012

31. Swerdloff RS, Dudley RE, Page ST, Wang C, Salameh WA. Dihydrotestosterone: Biochemistry, Physiology, and Clinical Implications of Elevated Blood Levels. Endocr Rev (2017) 38(3):220-54. doi: 10.1210/ er.2016-1067

32. Fluck CE, Meyer-Boni M, Pandey AV, Kempna P, Miller WL, Schoenle EJ, et al. Why Boys Will be Boys: Two Pathways of Fetal Testicular Androgen Biosynthesis are Needed for Male Sexual Differentiation. Am J Hum Genet (2011) 89(2):201-18. doi: 10.1016/j.ajhg.2011.06.009

33. Grino PB, Griffin JE, Wilson JD. Testosterone at High Concentrations Interacts With the Human Androgen Receptor Similarly to Dihydrotestosterone. Endocrinology (1990) 126(2):1165-72. doi: 10.1210/ endo-126-2-1165

34. Ramaswamy S, Weinbauer GF. Endocrine Control of Spermatogenesis: Role of FSH and LH/ Testosterone. Spermatogenesis (2014) 4(2):e996025. doi: $10.1080 / 21565562.2014 .996025$

35. Shang Y, Myers M, Brown M. Formation of the Androgen Receptor Transcription Complex. Mol Cell (2002) 9(3):601-10. doi: 10.1016/s10972765(02)00471-9

36. Saporita AJ, Zhang Q, Navai N, Dincer Z, Hahn J, Cai X, et al. Identification and Characterization of a Ligand-Regulated Nuclear Export Signal in Androgen Receptor. J Biol Chem (2003) 278(43):41998-2005. doi: $10.1074 / j b c . M 302460200$

37. Denayer S, Helsen C, Thorrez L, Haelens A, Claessens F. The Rules of DNA Recognition by the Androgen Receptor. Mol Endocrinol (2010) 24(5):898913. doi: 10.1210/me.2009-0310

38. Sahu B, Pihlajamaa P, Dubois V, Kerkhofs S, Claessens F, Janne OA. Androgen Receptor Uses Relaxed Response Element Stringency for Selective Chromatin Binding and Transcriptional Regulation. vivo Nucleic Acids Res (2014) 42(7):4230-40. doi: 10.1093/nar/gkt1401

39. Kallio PJ, Poukka H, Moilanen A, Jänne OA, Palvimo JJ. Androgen Receptor-Mediated Transcriptional Regulation in the Absence of Direct Interaction With a Specific DNA Element. Mol Endocrinol (1995) 9 (8):1017-28. doi: 10.1210/mend.9.8.7476976

40. Heckert LL, Wilson EM, Nilson JH. Transcriptional Repression of the Alpha-Subunit Gene by Androgen Receptor Occurs Independently of DNA Binding But Requires the DNA-Binding and Ligand-Binding Domains of the Receptor. Mol Endocrinol (1997) 11(10):1497-506. doi: $10.1210 /$ mend.11.10.9996

41. Fix C, Jordan C, Cano P, Walker WH. Testosterone Activates MitogenActivated Protein Kinase and the cAMP Response Element Binding Protein Transcription Factor in Sertoli Cells. Proc Natl Acad Sci USA (2004) 101 (30):10919-24. doi: 10.1073/pnas.0404278101

42. Deng Q, Wu Y, Zhang Z, Wang Y, Li M, Liang H, et al. Androgen Receptor Localizes to Plasma Membrane by Binding to Caveolin-1 in Mouse Sertoli Cells. Int J Endocrinol (2017) 2017:3985916. doi: 10.1155/2017/3985916

43. Cheng J, Watkins SC, Walker WH. Testosterone Activates MitogenActivated Protein Kinase via Src Kinase and the Epidermal Growth Factor Receptor in Sertoli Cells. Endocrinology (2007) 148(5):2066-74. doi: 10.1210/en.2006-1465

44. Deng Q, Zhang Z, Wu Y, Yu W-y, Zhang J, Jiang Z-M, et al. Non-Genomic Action of Androgens is Mediated by Rapid Phosphorylation and Regulation of Androgen Receptor Trafficking. Cell Physiol Biochem (2017) 43(1):22336. doi: $10.1159 / 000480343$

45. Toocheck C, Clister T, Shupe J, Crum C, Ravindranathan P, Lee TK, et al. Mouse Spermatogenesis Requires Classical and Nonclassical Testosterone Signaling. Biol Reprod (2016) 94(1):11. doi: 10.1095/biolreprod.115.132068
46. Lieberherr M, Grosse B. Androgens Increase Intracellular Calcium Concentration and Inositol 1,4,5-Trisphosphate and Diacylglycerol Formation via a Pertussis Toxin-Sensitive G-Protein. J Biol Chem (1994) 269(10):7217-23. doi: 10.1016/S0021-9258(17)37270-8

47. Von Ledebur EI, Almeida JP, Loss ES, Wassermann GF. Rapid Effect of Testosterone on Rat Sertoli Cell Membrane Potential. Relationship With K+ATP Channels. Horm Metab Res = Hormon- und Stoffwechselforschung = Horm Metabol (2002) 34(10):550-5. doi: 10.1055/s-2002-35426

48. Loss ES, Jacobsen M, Costa ZS, Jacobus AP, Borelli F, Wassermann GF. Testosterone Modulates $\mathrm{K}(+)$ ATP Channels in Sertoli Cell Membrane via the PLC-PIP2 Pathway. Horm Metab Res = Hormon- und Stoffwechselforschung $=$ Horm Metabol (2004) 36(8):519-25. doi: 10.1055/ s-2004-825753

49. Bulldan A, Dietze R, Shihan M, Scheiner-Bobis G. Non-Classical Testosterone Signaling Mediated Through ZIP9 Stimulates Claudin Expression and Tight Junction Formation in Sertoli Cells. Cell Signal (2016) 28(8):1075-85. doi: 10.1016/j.cellsig.2016.04.015

50. Lucas TF, Nascimento AR, Pisolato R, Pimenta MT, Lazari MF, Porto CS Receptors and Signaling Pathways Involved in Proliferation and Differentiation of Sertoli Cells. Spermatogenesis (2014) 4:e28138. doi: $10.4161 /$ spmg. 28138

51. Sharpe RM, McKinnell C, Kivlin C, Fisher JS. Proliferation and Functional Maturation of Sertoli Cells, and Their Relevance to Disorders of Testis Function in Adulthood. Reproduction (2003) 125(6):769-84. doi: 10.1530/ rep. 0.1250769

52. Legacki E, Conley AJ, Nitta-Oda BJ, Berger T. Porcine Sertoli Cell Proliferation After Androgen Receptor Inactivation. Biol Reprod (2015) 92 (4):93. doi: 10.1095/biolreprod.114.125716

53. Rojas-Garcia PP, Recabarren MP, Sir-Petermann T, Rey R, Palma S, Carrasco A, et al. Altered Testicular Development as a Consequence of Increase Number of Sertoli Cell in Male Lambs Exposed Prenatally to Excess Testosterone. Endocrine (2013) 43(3):705-13. doi: 10.1007/s12020-0129818-5

54. O'Shaughnessy PJ, Monteiro A, Abel M. Testicular Development in Mice Lacking Receptors for Follicle Stimulating Hormone and Androgen. PloS One (2012) 7(4):e35136. doi: 10.1371/journal.pone.0035136

55. Tan KA, Turner KJ, Saunders PT, Verhoeven G, De Gendt K, Atanassova N, et al. Androgen Regulation of Stage-Dependent Cyclin D2 Expression in Sertoli Cells Suggests a Role in Modulating Androgen Action on Spermatogenesis. Biol Reprod (2005) 72(5):1151-60. doi: 10.1095/ biolreprod.104.037689

56. Johnston H, Baker PJ, Abel M, Charlton HM, Jackson G, Fleming L, et al. Regulation of Sertoli Cell Number and Activity by Follicle-Stimulating Hormone and Androgen During Postnatal Development in the Mouse. Endocrinology (2004) 145(1):318-29. doi: 10.1210/en.2003-1055

57. Hu S, Liu D, Liu S, Li C, Guo J. Lycium Barbarum Polysaccharide Ameliorates Heat-Stress-Induced Impairment of Primary Sertoli Cells and the Blood-Testis Barrier in Rat via Androgen Receptor and Akt Phosphorylation. Evid Based Complement Alternat Med (2021) 2021:5574202. doi: 10.1155/2021/5574202

58. Edelsztein NY, Rey RA. Importance of the Androgen Receptor Signaling in Gene Transactivation and Transrepression for Pubertal Maturation of the Testis. Cells (2019) 8(8):861. doi: 10.3390/cells8080861

59. Shah W, Khan R, Shah B, Khan A, Dil S, Liu W, et al. The Molecular Mechanism of Sex Hormones on Sertoli Cell Development and Proliferation. Front Endocrinol (Lausanne) (2021) 12:648141. doi: 10.3389/fendo.2021. 648141

60. Martins AD, Alves MG, Simões VL, Dias TR, Rato L, Moreira PI, et al Control of Sertoli Cell Metabolism by Sex Steroid Hormones Is Mediated Through Modulation in Glycolysis-Related Transporters and Enzymes. Cell Tissue Res (2013) 354(3):861-8. doi: 10.1007/s00441-013-1722-7

61. Berger T. Testicular Estradiol and the Pattern of Sertoli Cell Proliferation in Prepuberal Bulls. Theriogenology (2019) 136:60-5. doi: 10.1016/ j.theriogenology.2019.06.031

62. Krzanowska H, Bilińska B. Number of Chromocentres in the Nuclei of Mouse Sertoli Cells in Relation to the Strain and Age of Males From Puberty to Senescence. J Reprod Fertil (2000) 118(2):343-50. doi: 10.1530/ jrf.0.1180343 
63. Shan LX, Bardin CW, Hardy MP. Immunohistochemical Analysis of Androgen Effects on Androgen Receptor Expression in Developing Leydig and Sertoli Cells. Endocrinology (1997) 138(3):1259-66. doi: 10.1210/ endo.138.3.4973

64. Josso N, Rey RA. What Does AMH Tell Us in Pediatric Disorders of Sex Development? Front Endocrinol (Lausanne) (2020) 11:619. doi: 10.3389/ fendo.2020.00619

65. da Rosa LA, Escott GM, Simonetti RB, da Silva JCD, Werlang ICR, Goldani $\mathrm{MZ}$, et al. Role of Non-Classical Effects of Testosterone and Epitestosterone on AMH Balance and Testicular Development Parameters. Mol Cell Endocrinol (2020) 511:110850. doi: 10.1016/j.mce.2020.110850

66. Lasala C, Schteingart HF, Arouche N, Bedecarrás P, Grinspon RP, Picard JY, et al. SOX9 and SF1 are Involved in Cyclic AMP-Mediated Upregulation of Anti-Mullerian Gene Expression in the Testicular Prepubertal Sertoli Cell Line SMAT1. Am J Physiol Endocrinol Metab (2011) 301(3):E539-47. doi: 10.1152/ajpendo.00187.2011

67. Edelsztein NY, Racine C, di Clemente N, Schteingart HF, Rey RA. Androgens Downregulate Anti-Mullerian Hormone Promoter Activity in the Sertoli Cell Through the Androgen Receptor and Intact Steroidogenic Factor 1 Sites. Biol Reprod (2018) 99(6):1303-12. doi: 10.1093/biolre/ioy152

68. Lan KC, Chen YT, Chang C, Chang YC, Lin HJ, Huang KE, et al. UpRegulation of SOX9 in Sertoli Cells From Testiculopathic Patients Accounts for Increasing Anti-Mullerian Hormone Expression Via Impaired Androgen Receptor Signaling. PloS One (2013) 8(10):e76303. doi: 10.1371/ journal.pone. 0076303

69. Wang G, Weng CC, Shao SH, Zhou W, de Gendt K, Braun RE, et al. Androgen Receptor in Sertoli Cells Is Not Required for TestosteroneInduced Suppression of Spermatogenesis, But Contributes to Sertoli Cell Organization in Utp14b Jsd Mice. J Androl (2009) 30(3):338-48. doi: $10.2164 /$ jandrol.108.006890

70. Willems A, Batlouni SR, Esnal A, Swinnen JV, Saunders PT, Sharpe RM, et al. Selective Ablation of the Androgen Receptor in Mouse Sertoli Cells Affects Sertoli Cell Maturation, Barrier Formation and Cytoskeletal Development. PloS One (2010) 5(11):e14168. doi: 10.1371/journal.pone.0014168

71. Chojnacka K, Brehm R, Weider K, Hejmej A, Lydka M, Kopera-Sobota I, et al. Expression of the Androgen Receptor in the Testis of Mice With a Sertoli Cell Specific Knock-Out of the Connexin 43 Gene (SCCx43KO(-/-)). Reprod Biol (2012) 12(4):341-6. doi: 10.1016/j.repbio.2012.10.007

72. De Gendt K, Denolet E, Willems A, Daniels VW, Clinckemalie L, Denayer S, et al. Expression of Tubb3, a Beta-Tubulin Isotype, Is Regulated by Androgens in Mouse and Rat Sertoli Cells. Biol Reprod (2011) 85(5):93445. doi: 10.1095/biolreprod.110.090704

73. Hazra R, Corcoran L, Robson M, McTavish KJ, Upton D, Handelsman DJ, et al. Temporal Role of Sertoli Cell Androgen Receptor Expression in Spermatogenic Development. Mol Endocrinol (2013) 27(1):12-24. doi: 10.1210/me.2012-1219

74. Hazra R, Upton D, Desai R, Noori O, Jimenez M, Handelsman DJ, et al. Elevated Expression of the Sertoli Cell Androgen Receptor Disrupts Male Fertility. Am J Physiol Endocrinol Metab (2016) 311(2):E396-404. doi: 10.1152/ajpendo.00159.2016

75. Itman C, Wong C, Hunyadi B, Ernst M, Jans DA, Loveland KL. Smad3 Dosage Determines Androgen Responsiveness and Sets the Pace of Postnatal Testis Development. Endocrinology (2011) 152(5):2076-89. doi: 10.1210/ en.2010-1453

76. Yang X, Feng Y, Li Y, Chen D, Xia X, Li J, et al. AR Regulates Porcine Immature Sertoli Cell Growth via Binding to RNF4 and miR-124a. Reprod Domest Anim (2021) 56(3):416-26. doi: 10.1111/rda.13877

77. Ma C, Song H, Yu L, Guan K, Hu P, Li Y, et al. miR-762 Promotes Porcine Immature Sertoli Cell Growth via the Ring Finger Protein 4 (RNF4) Gene. Sci Rep (2016) 6:32783. doi: 10.1038/srep32783

78. Li C, Yang B, Pan P, Ma Q, Wu Y, Zhang Z, et al. MicroRNA-130a Inhibits Spermatogenesis by Directly Targeting Androgen Receptor in Mouse Sertoli Cells. Mol Reprod Dev (2018) 85(10):768-77. doi: 10.1002/mrd.23058

79. Yao C, Sun M, Yuan Q, Niu M, Chen Z, Hou J, et al. MiRNA-133b Promotes the Proliferation of Human Sertoli Cells Through Targeting GLI3. Oncotarget (2016) 7(3):2201-19. doi: 10.18632/oncotarget.6876

80. Hu P, Guan K, Feng Y, Ma C, Song H, Li Y, et al. miR-638 Inhibits Immature Sertoli Cell Growth by Indirectly Inactivating PI3K/AKT Pathway via
SPAG1 Gene. Cell Cycle (2017) 16(23):2290-300. doi: 10.1080/ 15384101.2017.1380130

81. Raut S, Kumar AV, Deshpande S, Khambata K, Balasinor NH. Sex Hormones Regulate Lipid Metabolism in Adult Sertoli Cells: A GenomeWide Study of Estrogen and Androgen Receptor Binding Sites. J Steroid Biochem Mol Biol (2021) 211:105898. doi: 10.1016/j.jsbmb.2021.105898

82. Mou L, Zhang Q, Wang Y, Zhang Q, Sun L, Li C, et al. Identification of Ube2b as a Novel Target of Androgen Receptor in Mouse Sertoli Cells. Biol Reprod (2013) 89(2):32. doi: 10.1095/biolreprod.112.103648

83. Matzkin ME, Pellizzari EH, Rossi SP, Calandra RS, Cigorraga SB, Frungieri MB. Exploring the Cyclooxygenase 2 (COX2)/15d- $\Delta(12,14)$ PGJ(2) System in Hamster Sertoli Cells: Regulation by FSH/testosterone and Relevance to Glucose Uptake. Gen Comp Endocrinol (2012) 179(2):254-64. doi: 10.1016/ j.ygcen.2012.08.020

84. Tanaka T, Kanatsu-Shinohara M, Lei Z, Rao CV, Shinohara T. The Luteinizing Hormone-Testosterone Pathway Regulates Mouse Spermatogonial Stem Cell Self-Renewal by Suppressing WNT5A Expression in Sertoli Cells. Stem Cell Rep (2016) 7(2):279-91. doi: 10.1016/j.stemcr.2016.07.005

85. Crespo D, Lemos MS, Zhang YT, Safian D, Norberg B, Bogerd J, et al. PGE2 Inhibits Spermatogonia Differentiation in Zebrafish: Interaction With Fsh and an Androgen. J Endocrinol (2020) 244(1):163-75. doi: 10.1530/JOE-190309

86. Costoya JA, Hobbs RM, Barna M, Cattoretti G, Manova K, Sukhwani M, et al. Essential Role of Plzf in Maintenance of Spermatogonial Stem Cells. Nat Genet (2004) 36(6):653-9. doi: 10.1038/ng1367

87. Hermann BP, Sukhwani M, Lin CC, Sheng Y, Tomko J, Rodriguez M, et al. Characterization, Cryopreservation, and Ablation of Spermatogonial Stem Cells in Adult Rhesus Macaques. Stem Cells (2007) 25(9):2330-8. doi: 10.1634/stemcells.2007-0143

88. Wang J, Li J, Xu W, Xia Q, Gu Y, Song W, et al. Androgen Promotes Differentiation of PLZF $(+)$ Spermatogonia Pool via Indirect Regulatory Pattern. Cell Commun Signal (2019) 17(1):57. doi: 10.1186/s12964-0190369-8

89. Nobrega RH, Morais RD, Crespo D, de Waal PP, de Franca LR, Schulz RW, et al. Fsh Stimulates Spermatogonial Proliferation and Differentiation in Zebrafish via Igf3. Endocrinology (2015) 156(10):3804-17. doi: 10.1210/ en.2015-1157

90. Maiti S, Meistrich ML, Wilson G, Shetty G, Marcelli M, McPhaul MJ, et al. Irradiation Selectively Inhibits Expression From the Androgen-Dependent Pem Homeobox Gene Promoter in Sertoli Cells. Endocrinology (2001) 142 (4):1567-77. doi: 10.1210/endo.142.4.8076

91. Mayerhofer A. Peritubular Cells of the Human Testis: Prostaglandin E(2) and More. Andrology (2020) 8(4):898-902. doi: 10.1111/andr.12669

92. Zaker H, Razi M, Mahmoudian A, Soltanalinejad F. Boosting Effect of Testosterone on GDNF Expression in Sertoli Cell Line (TM4); Comparison Between TM3 Cells-Produced and Exogenous Testosterone. Gene (2022) 812:146112. doi: 10.1016/j.gene.2021.146112

93. Ma H, Cooke HJ, Shi Q. Meiosis: Recent Progress and New Opportunities. J Genet Genom (2014) 41(3):83-5. doi: 10.1016/j.jgg.2014.01.004

94. Chen SR, Hao XX, Zhang Y, Deng SL, Wang ZP, Wang YQ, et al. Androgen Receptor in Sertoli Cells Regulates DNA Double-Strand Break Repair and Chromosomal Synapsis of Spermatocytes Partially Through Intercellular EGF-EGFR Signaling. Oncotarget (2016) 7(14):18722-35. doi: 10.18632/ oncotarget.7916

95. O'Shaughnessy PJ. Hormonal Control of Germ Cell Development and Spermatogenesis. Semin Cell Dev Biol (2014) 29:55-65. doi: 10.1016/ j.semcdb.2014.02.010

96. De Gendt K, Swinnen JV, Saunders PT, Schoonjans L, Dewerchin M, Devos A, et al. A Sertoli Cell-Selective Knockout of the Androgen Receptor Causes Spermatogenic Arrest in Meiosis. Proc Natl Acad Sci USA (2004) 101 (5):1327-32. doi: 10.1073/pnas.0308114100

97. Su L, Mruk DD, Lee WM, Cheng CY. Differential Effects of Testosterone and TGF-Beta3 on Endocytic Vesicle-Mediated Protein Trafficking Events at the Blood-Testis Barrier. Exp Cell Res (2010) 316(17):2945-60. doi: 10.1016/ j.yexcr.2010.07.018

98. Larose H, Kent T, Ma Q, Shami AN, Harerimana N, Li JZ, et al. Regulation of Meiotic Progression by Sertoli-Cell Androgen Signaling. Mol Biol Cell (2020) 31(25):2841-62. doi: 10.1091/mbc.E20-05-0334 
99. Stanton PG, Sluka P, Foo CF, Stephens AN, Smith AI, McLachlan RI, et al. Proteomic Changes in Rat Spermatogenesis in Response to In Vivo Androgen Manipulation; Impact on Meiotic Cells. PloS One (2012) 7(7): e41718. doi: 10.1371/journal.pone.0041718

100. Yang L, Wang Y, Zhang Q, Lai Y, Li C, Zhang Q, et al. Identification of Hsf1 as a Novel Androgen Receptor-Regulated Gene in Mouse Sertoli Cells. Mol Reprod Dev (2014) 81(6):514-23. doi: 10.1002/mrd.22318

101. Hu Z, Shanker S, MacLean JA2nd, Ackerman SL, Wilkinson MF. The RHOX5 Homeodomain Protein Mediates Transcriptional Repression of the Netrin-1 Receptor Gene Unc5c. J Biol Chem (2008) 283(7):3866-76. doi: 10.1074/jbc.M706717200

102. Lindsey JS, Wilkinson MF. Pem: A Testosterone- and LH-Regulated Homeobox Gene Expressed in Mouse Sertoli Cells and Epididymis. Dev Biol (1996) 179(2):471-84. doi: 10.1006/dbio.1996.0276

103. Bhardwaj A, Sohni A, Lou CH, De Gendt K, Zhang F, Kim E, et al. Concordant Androgen-Regulated Expression of Divergent Rhox5 Promoters in Sertoli Cells. Endocrinology (2022) 163(1):1-17. doi: 10.1210/ endocr/bqab237

104. Câmara ML, Almeida TB, de Santi F, Rodrigues BM, Cerri PS, Beltrame FL, et al. Fluoxetine-Induced Androgenic Failure Impairs the Seminiferous Tubules Integrity and Increases Ubiquitin Carboxyl-Terminal Hydrolase L1 (UCHL1): Possible Androgenic Control of UCHL1 in Germ Cell Death? Biomed Pharmacother = Biomed Pharmacother (2019) 109:1126-39. doi: 10.1016/j.biopha.2018.10.034

105. Elliott MR, Zheng S, Park D, Woodson RI, Reardon MA, Juncadella IJ, et al. Unexpected Requirement for ELMO1 in Clearance of Apoptotic Germ Cells In Vivo. Nature (2010) 467(7313):333-7. doi: 10.1038/nature09356

106. Wu RC, Jiang M, Beaudet AL, Wu MY. ARID4A and ARID4B Regulate Male Fertility, a Functional Link to the AR and RB Pathways. Proc Natl Acad Sci USA (2013) 110(12):4616-21. doi: 10.1073/pnas.1218318110

107. Wu RC, Zeng Y, Pan IW, Wu MY. Androgen Receptor Coactivator ARID4B Is Required for the Function of Sertoli Cells in Spermatogenesis. Mol Endocrinol (2015) 29(9):1334-46. doi: 10.1210/me.2015-1089

108. Domanskyi A, Zhang FP, Nurmio M, Palvimo JJ, Toppari J, Janne OA. Expression and Localization of Androgen Receptor-Interacting Protein-4 in the Testis. Am J Physiol Endocrinol Metab (2007) 292(2):E513-22. doi: 10.1152/ajpendo.00287.2006

109. Vija L, Meduri G, Comperat E, Vasiliu V, Izard V, Ferlicot S, et al. Expression and Characterization of Androgen Receptor Coregulators, SRC-2 and HBO1, During Human Testis Ontogenesis and in Androgen Signaling Deficient Patients. Mol Cell Endocrinol (2013) 375(1-2):140-8. doi: 10.1016/ j.mce.2013.05.004

110. Tan JA, Hall SH, Petrusz P, French FS. Thyroid Receptor Activator Molecule, TRAM-1, Is an Androgen Receptor Coactivator. Endocrinology (2000) 141 (9):3440-50. doi: 10.1210/endo.141.9.7680

111. Kuwahara S, Ikei A, Taguchi Y, Tabuchi Y, Fujimoto N, Obinata M, et al. PSPC1, NONO, and SFPQ Are Expressed in Mouse Sertoli Cells and may Function as Coregulators of Androgen Receptor-Mediated Transcription. Biol Reprod (2006) 75(3):352-9. doi: 10.1095/biolreprod.106.051136

112. Kumar A, Dumasia K, Deshpande S, Balasinor NH. Direct Regulation of Genes Involved in Sperm Release by Estrogen and Androgen Through Their Receptors and Coregulators. J Steroid Biochem Mol Biol (2017) 171:66-74. doi: 10.1016/j.jsbmb.2017.02.017

113. Terada K, Yomogida K, Imai T, Kiyonari H, Takeda N, Kadomatsu T, et al. A Type I DnaJ Homolog, DjA1, Regulates Androgen Receptor Signaling and Spermatogenesis. EMBO J (2005) 24(3):611-22. doi: 10.1038/ sj.emboj.7600549

114. Guillermet-Guibert J, Smith LB, Halet G, Whitehead MA, Pearce W, Rebourcet D, et al. Novel Role for P110beta PI 3-Kinase in Male Fertility Through Regulation of Androgen Receptor Activity in Sertoli Cells. PloS Genet (2015) 11(7):e1005304. doi: 10.1371/journal.pgen.1005304

115. Furu K, Klungland A. Tzfp Represses the Androgen Receptor in Mouse Testis. PloS One (2013) 8(4):e62314. doi: 10.1371/journal.pone.0062314

116. Zhang L, Charron M, Wright WW, Chatterjee B, Song CS, Roy AK, et al. Nuclear factor-kappaB Activates Transcription of the Androgen Receptor Gene in Sertoli Cells Isolated From Testes of Adult Rats. Endocrinology (2004) 145(2):781-9. doi: 10.1210/en.2003-0987
117. Zhao Z, Qiao L, Dai Z, He Q, Lan X, Huang S, et al. LncNONO-AS Regulates AR Expression by Mediating NONO. Theriogenology (2020) 145:198-206. doi: 10.1016/j.theriogenology.2019.10.025

118. Gonzalez-Herrera IG, Prado-Lourenco L, Pileur F, Conte C, Morin A, Cabon F, et al. Testosterone Regulates FGF-2 Expression During Testis Maturation by an IRES-Dependent Translational Mechanism. FASEB J (2006) 20 (3):476-8. doi: 10.1096/fj.04-3314fje

119. Geng Q, Ni LW, Ouyang B, Hu YH, Zhao Y, Guo J. Alanine and Arginine Rich Domain Containing Protein, Aard, Is Directly Regulated by Androgen Receptor in Mouse Sertoli Cells. Mol Med Rep (2017) 15(1):352-8. doi: $10.3892 / \mathrm{mmr} .2016 .6028$

120. El Chami N, Ikhlef F, Kaszas K, Yakoub S, Tabone E, Siddeek B, et al. Androgen-Dependent Apoptosis in Male Germ Cells is Regulated Through the Proto-Oncoprotein Cbl. J Cell Biol (2005) 171(4):651-61. doi: 10.1083/ jcb.200507076

121. Sun R, Liang H, Guo H, Wang Z, Deng Q. PMCA4 Gene Expression is Regulated by the Androgen Receptor in the Mouse Testis During Spermatogenesis. Mol Med Rep (2021) 23(2):152. doi: 10.3892/ mmr.2020.11791

122. Silva EJ, Patrao MT, Tsuruta JK, O'Rand MG, Avellar MC. Epididymal Protease Inhibitor (EPPIN) is Differentially Expressed in the Male Rat Reproductive Tract and Immunolocalized in Maturing Spermatozoa. Mol Reprod Dev (2012) 79(12):832-42. doi: 10.1002/mrd.22119

123. Eacker SM, Shima JE, Connolly CM, Sharma M, Holdcraft RW, Griswold MD, et al. Transcriptional Profiling of Androgen Receptor (AR) Mutants Suggests Instructive and Permissive Roles of AR Signaling in Germ Cell Development. Mol Endocrinol (2007) 21(4):895-907. doi: 10.1210/me.20060113

124. Yan HH, Mruk DD, Lee WM, Cheng CY. Blood-Testis Barrier Dynamics are Regulated by Testosterone and Cytokines via Their Differential Effects on the Kinetics of Protein Endocytosis and Recycling in Sertoli Cells. FASEB J (2008) 22(6):1945-59. doi: 10.1096/fj.06-070342

125. Meng J, Greenlee AR, Taub CJ, Braun RE. Sertoli Cell-Specific Deletion of the Androgen Receptor Compromises Testicular Immune Privilege in Mice. Biol Reprod (2011) 85(2):254-60. doi: 10.1095/biolreprod.110.090621

126. Li MW, Xia W, Mruk DD, Wang CQ, Yan HH, Siu MK, et al. Tumor Necrosis Factor \{Alpha\} Reversibly Disrupts the Blood-Testis Barrier and Impairs Sertoli-Germ Cell Adhesion in the Seminiferous Epithelium of Adult Rat Testes. J Endocrinol (2006) 190(2):313-29. doi: 10.1677/joe.1.06781

127. Meng J, Holdcraft RW, Shima JE, Griswold MD, Braun RE. Androgens Regulate the Permeability of the Blood-Testis Barrier. Proc Natl Acad Sci USA (2005) 102(46):16696-700. doi: 10.1073/pnas.0506084102

128. Kaitu'u-Lino TJ, Sluka P, Foo CF, Stanton PG. Claudin-11 Expression and Localisation is Regulated by Androgens in Rat Sertoli Cells In Vitro. Reproduction (2007) 133(6):1169-79. doi: 10.1530/REP-06-0385

129. Chakraborty P, William Buaas F, Sharma M, Smith BE, Greenlee AR, Eacker SM, et al. Androgen-Dependent Sertoli Cell Tight Junction Remodeling is Mediated by Multiple Tight Junction Components. Mol Endocrinol (2014) 28 (7):1055-72. doi: 10.1210/me.2013-1134

130. Denolet E, De Gendt K, Allemeersch J, Engelen K, Marchal K, Van Hummelen P, et al. The Effect of a Sertoli Cell-Selective Knockout of the Androgen Receptor on Testicular Gene Expression in Prepubertal Mice. Mol Endocrinol (2006) 20(2):321-34. doi: 10.1210/me.2005-0113

131. Wang RS, Yeh S, Chen LM, Lin HY, Zhang C, Ni J, et al. Androgen Receptor in Sertoli Cell is Essential for Germ Cell Nursery and Junctional Complex Formation in Mouse Testes. Endocrinology (2006) 147(12):5624-33. doi: 10.1210/en.2006-0138

132. Traweger A, Fuchs R, Krizbai IA, Weiger TM, Bauer HC, Bauer H. The Tight Junction Protein ZO-2 Localizes to the Nucleus and Interacts With the Heterogeneous Nuclear Ribonucleoprotein Scaffold Attachment Factor-B. J Biol Chem (2003) 278(4):2692-700. doi: 10.1074/jbc.M206821200

133. Guo J, Shi YQ, Yang W, Li YC, Hu ZY, Liu YX. Testosterone Upregulation of Tissue Type Plasminogen Activator Expression in Sertoli Cells: tPA Expression in Sertoli Cells. Endocrine (2007) 32(1):83-9. doi: 10.1007/ s12020-007-9014-1

134. Gunnarsson M, Lecander I, Abrahamsson PA. Factors of the Plasminogen Activator System in Human Testis, as Demonstrated by in-Situ 
Hybridization and Immunohistochemistry. Mol Hum Reprod (1999) 5 (10):934-40. doi: 10.1093/molehr/5.10.934

135. Dietze R, Shihan M, Stammler A, Konrad L, Scheiner-Bobis G. Cardiotonic Steroid Ouabain Stimulates Expression of Blood-Testis Barrier Proteins Claudin-1 and -11 and Formation of Tight Junctions in Sertoli Cells. Mol Cell Endocrinol (2015) 405:1-13. doi: 10.1016/j.mce.2015.02.004

136. Papadopoulos D, Dietze R, Shihan M, Kirch U, Scheiner-Bobis G. Dehydroepiandrosterone Sulfate Stimulates Expression of Blood-TestisBarrier Proteins Claudin-3 and -5 and Tight Junction Formation via a Gnalpha11-Coupled Receptor in Sertoli Cells. PloS One (2016) 11(3): e0150143. doi: 10.1371/journal.pone.0150143

137. Li XX, Chen SR, Shen B, Yang JL, Ji SY, Wen Q, et al. The Heat-Induced Reversible Change in the Blood-Testis Barrier (BTB) Is Regulated by the Androgen Receptor (AR) via the Partitioning-Defective Protein (Par) Polarity Complex in the Mouse. Biol Reprod (2013) 89(1):12. doi: 10.1095/ biolreprod.113.109405

138. Kopera I, Durlej M, Hejmej A, Knapczyk-Stwora K, Duda M, Slomczynska M, et al. Differential Expression of Connexin 43 in Adult Pig Testes During Normal Spermatogenic Cycle and After Flutamide Treatment. Reprod Domest Anim (2011) 46(6):1050-60. doi: 10.1111/j.1439-0531.2011.01783.x

139. Xia Q, Zhang D, Wang J, Zhang X, Song W, Chen R, et al. Androgen Indirectly Regulates Gap Junction Component Connexin 43 Through Wilms Tumor-1 in Sertoli Cells. Stem Cells Dev (2020) 29(3):169-76. doi: 10.1089/ scd.2019.0166

140. Rajamanickam GD, Kastelic JP, Thundathil JC. The Ubiquitous Isoform of $\mathrm{Na} / \mathrm{K}-\mathrm{ATPase}$ (ATP1A1) Regulates Junctional Proteins, Connexin 43 and Claudin 11 via Src-EGFR-ERK1/2-CREB Pathway in Rat Sertoli Cells. Biol Reprod (2017) 96(2):456-68. doi: 10.1095/biolreprod.116.141267

141. McCabe MJ, Allan CM, Foo CF, Nicholls PK, McTavish KJ, Stanton PG. Androgen Initiates Sertoli Cell Tight Junction Formation in the Hypogonadal (Hpg) Mouse. Biol Reprod (2012) 87(2):38. doi: 10.1095/ biolreprod.111.094318

142. Mruk DD, Cheng CY. The Mammalian Blood-Testis Barrier: Its Biology and Regulation. Endocr Rev (2015) 36(5):564-91. doi: 10.1210/er.2014-1101

143. Bruewer M, Utech M, Ivanov AI, Hopkins AM, Parkos CA, Nusrat A. Interferon-Gamma Induces Internalization of Epithelial Tight Junction Proteins via a Macropinocytosis-Like Process. FASEB J (2005) 19(8):92333. doi: 10.1096/fj.04-3260com

144. Shen L, Turner JR. Actin Depolymerization Disrupts Tight Junctions via Caveolae-Mediated Endocytosis. Mol Biol Cell (2005) 16(9):3919-36. doi: 10.1091/mbc.e04-12-1089

145. Su L, Mruk DD, Lee WM, Cheng CY. Differential Effects of Testosterone and TGF- $\beta 3$ on Endocytic Vesicle-Mediated Protein Trafficking Events at the Blood-Testis Barrier. Exp Cell Res (2010) 316(17):2945-60. doi: 10.1016/ j.yexcr.2010.07.018

146. Yin L, Lu L, Lin X, Wang X. Crucial Role of Androgen Receptor in Resistance and Endurance Trainings-Induced Muscle Hypertrophy Through IGF-1/ IGF-1r- PI3K/Akt- mTOR Pathway. Nutr Metab (Lond) (2020) 17:26. doi: 10.1186/s12986-020-00446-y

147. Wei Y, Zhou Y, Long C, Wu H, Hong Y, Fu Y, et al. Polystyrene Microplastics Disrupt the Blood-Testis Barrier Integrity Through ROSMediated Imbalance of Mtorc1 and Mtorc2. Environ Pollut (2021) 289:117904. doi: 10.1016/j.envpol.2021.117904

148. McLachlan RI, Wreford NG, O'Donnell L, de Kretser DM, Robertson DM. The Endocrine Regulation of Spermatogenesis: Independent Roles for Testosterone and FSH. J Endocrinol (1996) 148(1):1-9. doi: 10.1677/ joe. 0.1480001

149. Beardsley A, O'Donnell L. Characterization of Normal Spermiation and Spermiation Failure Induced by Hormone Suppression in Adult Rats. Biol Reprod (2003) 68(4):1299-307. doi: 10.1095/biolreprod.102.009811

150. Holdcraft RW, Braun RE. Androgen Receptor Function is Required in Sertoli Cells for the Terminal Differentiation of Haploid Spermatids. Development (2004) 131(2):459-67. doi: 10.1242/dev.00957

151. Walker WH. Non-Classical Actions of Testosterone and Spermatogenesis. Philos Trans R Soc Lond B Biol Sci (2010) 365(1546):1557-69. doi: 10.1098/ rstb.2009.0258

152. Shupe J, Cheng J, Puri P, Kostereva N, Walker WH. Regulation of SertoliGerm Cell Adhesion and Sperm Release by FSH and Nonclassical
Testosterone Signaling. Mol Endocrinol (2011) 25(2):238-52. doi: 10.1210/ me.2010-0030

153. Zhang J, Wong CH, Xia W, Mruk DD, Lee NP, Lee WM, et al. Regulation of Sertoli-Germ Cell Adherens Junction Dynamics via Changes in ProteinProtein Interactions of the N-Cadherin-Beta-Catenin Protein Complex Which are Possibly Mediated by C-Src and Myotubularin-Related Protein 2: An In Vivo Study Using an Androgen Suppression Model. Endocrinology (2005) 146(3):1268-84. doi: 10.1210/en.2004-1194

154. Dufau ML, Kavarthapu R. Gonadotropin Regulation Testicular RNA Helicase, Two Decades of Studies on Its Structure Function and Regulation From Its Discovery Opens a Window for Development of a Non-Hormonal Oral Male Contraceptive. Front Endocrinol (Lausanne) (2019) 10:576. doi: 10.3389/fendo.2019.00576

155. Tang PZ, Tsai-Morris CH, Dufau ML. A Novel Gonadotropin-Regulated Testicular RNA Helicase. A New Member of the Dead-Box Family. J Biol Chem (1999) 274(53):37932-40. doi: 10.1074/jbc.274.53.37932

156. Sheng Y, Tsai-Morris CH, Gutti R, Maeda Y, Dufau ML. GonadotropinRegulated Testicular RNA Helicase (GRTH/Ddx25) is a Transport Protein Involved in Gene-Specific mRNA Export and Protein Translation During Spermatogenesis. J Biol Chem (2006) 281(46):35048-56. doi: 10.1074/ jbc.M605086200

157. Villar J, Tsai-Morris CH, Dai L, Dufau ML. Androgen-Induced Activation of Gonadotropin-Regulated Testicular RNA Helicase (GRTH/Ddx25) Transcription: Essential Role of a Nonclassical Androgen Response Element Half-Site. Mol Cell Biol (2012) 32(8):1566-80. doi: 10.1128/mcb.06002-11

158. Kavarthapu R, Dufau ML. Germ Cell Nuclear Factor (GCNF/RTR) Regulates Transcription of Gonadotropin-Regulated Testicular RNA Helicase (GRTH/ DDX25) in Testicular Germ Cells-The Androgen Connection. Mol Endocrinol (2015) 29(12):1792-804. doi: 10.1210/me.2015-1198

159. Yang TA, Yang YH, Song XC, Liu LL, Yang YF, Xing XM, et al. Comparative Studies on Testis, Epididymis and Serum Hormone Concentrations in Foxes, and Hybrids During the Pre-Breeding Period. Anim Reprod Sci (2019) 203:61-7. doi: 10.1016/j.anireprosci.2019.02.008

160. Ando K, Tomimura K, Sazdovitch V, Suain V, Yilmaz Z, Authelet M, et al. Level of PICALM, a Key Component of Clathrin-Mediated Endocytosis, is Correlated With Levels of Phosphotau and Autophagy-Related Proteins and Is Associated With Tau Inclusions in AD, PSP and Pick Disease. Neurobiol Dis (2016) 94:32-43. doi: 10.1016/j.nbd.2016.05.017

161. Russell LD, Clermont Y. Degeneration of Germ Cells in Normal, Hypophysectomized and Hormone Treated Hypophysectomized Rats. Anatomical Rec (1977) 187(3):347-66. doi: 10.1002/ar.1091870307

162. O'Donnell L, McLachlan RI, Wreford NG, de Kretser DM, Robertson DM. Testosterone Withdrawal Promotes Stage-Specific Detachment of Round Spermatids From the Rat Seminiferous Epithelium. Biol Reprod (1996) 55 (4):895-901. doi: 10.1095/biolreprod55.4.895

163. Lee NP, Cheng CY. Protein Kinases and Adherens Junction Dynamics in the Seminiferous Epithelium of the Rat Testis. J Cell Physiol (2005) 202(2):34460. doi: $10.1002 /$ jcp. 20119

164. Chapin RE, Wine RN, Harris MW, Borchers CH, Haseman JK. Structure and Control of a Cell-Cell Adhesion Complex Associated With Spermiation in Rat Seminiferous Epithelium. J Androl (2001) 22(6):1030-52. doi: 10.1002/ j.1939-4640.2001.tb03444.x

165. Olli KE, Li K, Galileo DS, Martin-DeLeon PA. Plasma Membrane Calcium ATPase 4 (PMCA4) Co-Ordinates Calcium and Nitric Oxide Signaling in Regulating Murine Sperm Functional Activity. J Cell Physiol (2018) 233 (1):11-22. doi: $10.1002 / j c p .25882$

166. Agarwal A, Mulgund A, Hamada A, Chyatte MR. A Unique View on Male Infertility Around the Globe. Reprod Biol Endocrinol (2015) 13:37. doi: 10.1186/s12958-015-0032-1

167. Hajder M, Hajder E, Husic A. The Effects of Total Motile Sperm Count on Spontaneous Pregnancy Rate and Pregnancy After IUI Treatment in Couples With Male Factor and Unexplained Infertility. Med Arch (2016) 70(1):39-43. doi: 10.5455/medarh.2016.70.39-43

168. Hornig NC, Holterhus PM. Molecular Basis of Androgen Insensitivity Syndromes. Mol Cell Endocrinol (2021) 523:111146. doi: 10.1016/ j.mce.2020.111146

169. Witchel SF. Disorders of Sex Development. Best Pract Res Clin Obstet Gynaecol (2018) 48:90-102. doi: 10.1016/j.bpobgyn.2017.11.005 
170. Veyssiere G, Berger M, Jean-Faucher C, de Turckheim M, Jean C. Testosterone and Dihydrotestosterone in Sexual Ducts and Genital Tubercle of Rabbit Fetuses During Sexual Organogenesis: Effects of Fetal Decapitation. J Steroid Biochem (1982) 17(2):149-54. doi: 10.1016/00224731(82)90114-5

171. Adachi M, Takayanagi R, Tomura A, Imasaki K, Kato S, Goto K, et al. Androgen-Insensitivity Syndrome as a Possible Coactivator Disease. N Engl J Med (2000) 343(12):856-62. doi: 10.1056/nejm200009213431205

172. Oakes MB, Eyvazzadeh AD, Quint E, Smith YR. Complete Androgen Insensitivity Syndrome-a Review. J Pediatr Adolesc Gynecol (2008) 21 (6):305-10. doi: 10.1016/j.jpag.2007.09.006

173. Hellmann P, Christiansen P, Johannsen TH, Main KM, Duno M, Juul A. Male Patients With Partial Androgen Insensitivity Syndrome: A Longitudinal Follow-Up of Growth, Reproductive Hormones and the Development of Gynaecomastia. Arch Dis Child (2012) 97(5):403-9. doi: 10.1136/archdischild-2011-300584

174. Hage M, Drui D, Francou B, Mercier S, Guiochon-Mantel A, Belaisch-Allart J, et al. Structural Analysis of the Impact of a Novel Androgen Receptor Gene Mutation in Two Adult Patients With Mild Androgen Insensitivity Syndrome. Andrologia (2021) 53(1):e13865. doi: 10.1111/and.13865

175. Gulía C, Baldassarra S, Zangari A, Briganti V, Gigli S, Gaffi M, et al. Androgen Insensitivity Syndrome. Eur Rev Med Pharmacol Sci (2018) 22 (12):3873-87. doi: 10.26355/eurrev_201806_15272

176. Deeb A, Mason C, Lee YS, Hughes IA. Correlation Between Genotype, Phenotype and Sex of Rearing in 111 Patients With Partial Androgen Insensitivity Syndrome. Clin Endocrinol (2005) 63(1):56-62. doi: 10.1111/ j.1365-2265.2005.02298.x

177. Gottlieb B, Lehvaslaiho H, Beitel LK, Lumbroso R, Pinsky L, Trifiro M. The Androgen Receptor Gene Mutations Database. Nucleic Acids Res (1998) 26 (1):234-8. doi: 10.1093/nar/26.1.234

178. Bukhari I, Li G, Wang L, Iqbal F, Zhang H, Zhu J, et al. Effects of Androgen Receptor Mutation on Testicular Histopathology of Patient Having Complete Androgen Insensitivity. J Mol Histol (2017) 48(3):159-67. doi: 10.1007/s10735-017-9714-7

179. Cortes D, Clasen-Linde E, Hutson JM, Li R, Thorup J. The Sertoli Cell Hormones Inhibin-B and Anti Mullerian Hormone Have Different Patterns of Secretion in Prepubertal Cryptorchid Boys. J Pediatr Surg (2016) 51 (3):475-80. doi: 10.1016/j.jpedsurg.2015.08.059

180. Schweikert HU, Milewich L, Wilson JD. Aromatization of Androstenedione by Cultured Human Fibroblasts. J Clin Endocrinol Metab (1976) 43(4):78595. doi: 10.1210/jcem-43-4-785

181. Appari M, Werner R, Wunsch L, Cario G, Demeter J, Hiort O, et al. Apolipoprotein D (APOD) Is a Putative Biomarker of Androgen Receptor
Function in Androgen Insensitivity Syndrome. J Mol Med (Berl) (2009) 87 (6):623-32. doi: 10.1007/s00109-009-0462-3

182. Holterhus PM, Deppe U, Werner R, Richter-Unruh A, Bebermeier JH, Wunsch L, et al. Intrinsic Androgen-Dependent Gene Expression Patterns Revealed by Comparison of Genital Fibroblasts From Normal Males and Individuals With Complete and Partial Androgen Insensitivity Syndrome. BMC Genomics (2007) 8:376. doi: 10.1186/1471-2164-8-376

183. Shah R, Woolley MM, Costin G. Testicular Feminization: The Androgen Insensitivity Syndrome. J Pediatr Surg (1992) 27(6):757-60. doi: 10.1016/ s0022-3468(05)80110-1

184. Dahiya S, Singh M, Mandal S, Jain SL, Rathore A, Lal P. Androgen Insensitivity Syndrome: Can Cytology Help? Cytopathology (2021) 33 (2);249-52. doi: 10.1111/cyt.13064

185. Hannema SE, Scott IS, Rajpert-De Meyts E, Skakkebaek NE, Coleman N, Hughes IA. Testicular Development in the Complete Androgen Insensitivity Syndrome. J Pathol (2006) 208(4):518-27. doi: 10.1002/path.1890

186. Looijenga LH, Hersmus R, Oosterhuis JW, Cools M, Drop SL, Wolffenbuttel KP. Tumor Risk in Disorders of Sex Development (DSD). Best Pract Res Clin Endocrinol Metab (2007) 21(3):480-95. doi: 10.1016/j.beem.2007.05.001

187. Hughes IA, Davies JD, Bunch TI, Pasterski V, Mastroyannopoulou K, MacDougall J. Androgen Insensitivity Syndrome. Lancet (2012) 380 (9851):1419-28. doi: 10.1016/s0140-6736(12)60071-3

188. Walker WH, Easton E, Moreci RS, Toocheck C, Anamthathmakula P, Jeyasuria P. Restoration of Spermatogenesis and Male Fertility Using an Androgen Receptor Transgene. PloS One (2015) 10(3):e0120783. doi: 10.1371/journal.pone.0120783

Conflict of Interest: The authors declare that the research was conducted in the absence of any commercial or financial relationships that could be construed as a potential conflict of interest.

Publisher's Note: All claims expressed in this article are solely those of the authors and do not necessarily represent those of their affiliated organizations, or those of the publisher, the editors and the reviewers. Any product that may be evaluated in this article, or claim that may be made by its manufacturer, is not guaranteed or endorsed by the publisher.

Copyright (c) 2022 Wang, Li and Yang. This is an open-access article distributed under the terms of the Creative Commons Attribution License (CC BY). The use, distribution or reproduction in other forums is permitted, provided the original author(s) and the copyright owner(s) are credited and that the original publication in this journal is cited, in accordance with accepted academic practice. No use, distribution or reproduction is permitted which does not comply with these terms. 


\section{GLOSSARY}

$11-\mathrm{K}$

Aard

AIS

$\mathrm{AMH}$

APOD

ARE

ARID4AVAB

ARIP4

$\mathrm{AR}$

ARKO

BTB

Btc

CAIS

$\mathrm{Cbl}$

CK18

CRE

CREB

Cx43

DHT

DjA1

DSBs

Eea1

EGFR

Elmo1

ES

FAK

FGF2

GATA-2

GC

GCNF

GDNF

GJ

GPI

GRTH/DDX25

hpg

lgf3

$\mathrm{Hsf1}$

IncNONO-AS 11-ketotestosterone

alanine and arginine rich domain

Androgen insensitive syndrome

Anti Mullerian hormone

apolipoprotein D

Androgen response element

AT-rich interaction domain 4A/4B

androgen receptor-interacting protein 4

androgen receptor

Androgen receptor knock out

Blood-testis barrier

betacellulin

Complete androgen insensitive syndrome

calcineurin B-like protein

Cytokeratin 18

cAMP-response element

CAMP-response element-binding protein

connexin 43

Dihydrotestosterone

type 1 DnaJ protein

DNA double strand breaks

early endosome antigen 1

Epidermal growth factor receptor

engulfment and cell motility 1

Ectoplasmic specialization

Focal adhesion kinase

Fibroblast growth factor 2

GATA binding protein 2

Germ cell

Germ cell nuclear factor

Glial-derived neurotrophic factor

gap junction

Glycosylphosphatidylinositol

Gonadotropin Regulated Testicular Helicase

hypogonadal

Insulin like growth factor 3

Heat shock transcription factor 1

target NONO IncRNA
Continued

\begin{tabular}{|c|c|}
\hline MAIS & Mild androgen insensitive syndrome \\
\hline NASP & nuclear autoantigenic sperm protein \\
\hline NCoR1 & nuclear receptor corepressor 1 \\
\hline Nrg1 & neuregulin 1 \\
\hline NONO & non-POU domain-containing octamer-binding protein \\
\hline $\mathrm{p}^{90 R S K}$ & ribosomal protein S6 kinase $\mathrm{A} 1$ \\
\hline PAIS & Partial androgen insensitive syndrome \\
\hline PGE2 & prostaglandin E2 \\
\hline PI3K & phosphatidylinositol 3 kinase \\
\hline Picalm & phosphatidylinositol binding clathrin assembly protein \\
\hline Plzf & Promyelocytic leukemia zinc finger \\
\hline PMCA4 & ATPase $\mathrm{Ca}^{++}$transporting plasma membrane 4 \\
\hline PSPC-1 & paraspeckle component 1 \\
\hline Rhox5 & Reproductive homeobox 5 gene \\
\hline RNF4 & really interesting new gene (RING) finger protein 4 \\
\hline SC & Sertoli cell \\
\hline SCARKO & Sertoli cell androgen receptor knock out \\
\hline SF1 & steroidogenic factor 1 \\
\hline SFPQ & splicing factor proline/glutamine rich \\
\hline SOX9 & sex determining region $Y$-box 9 \\
\hline Spinlw1 & Epididymal protease inhibitor \\
\hline Src & SRC proto-oncogene \\
\hline Src1 & steroid receptor coactivator-1 \\
\hline SSC & Spermatogonia stem cell \\
\hline Stx5a & syntaxin 5 \\
\hline $\mathrm{T}$ & testosterone \\
\hline TE & testosterone and oestradiol \\
\hline Tfm & testicular feminized mouse \\
\hline tPA & type plasminogen activator \\
\hline TJ & tight junction \\
\hline TRAM-1 & thyroid hormone receptor activator molecule-1 \\
\hline TUBB3 & Class III $\beta$ tubulin \\
\hline Tzfp & testis zinc finger protein \\
\hline Ube2b & ubiquitin-conjugating enzyme E2B \\
\hline $\mathrm{UCHC} 1$ & ubiquitincarboxyl-terminal hydrolase L1 \\
\hline UNC5C & Unc-5 Netrin Receptor C(UNC5C) \\
\hline Wnt5a & $\begin{array}{l}\text { Wingless-type MMTV Integration Site Family } \\
\text { Member } 5 \mathrm{~A}\end{array}$ \\
\hline Wt1 & WT1 transcription factor \\
\hline ZIP9 & Zrt- and Irt-like protein 9. \\
\hline
\end{tabular}

